\title{
Organic Nanomaterials and Their Applications in the Treatment of Oral Diseases
}

\author{
Maria Justina Roxana Virlan ${ }^{1}$, Daniela Miricescu ${ }^{1}$, Radu Radulescu ${ }^{1}$, Cristina M. Sabliov ${ }^{2}$, \\ Alexandra Totan ${ }^{1}$, Bogdan Calenic ${ }^{1, *}$ and Maria Greabu ${ }^{1}$ \\ 1 Department of Biochemistry, Faculty of Dentistry, University of Medicine and Pharmacy Carol Davila, Blvd. \\ EroiiSanitari, No. 8, RO-050474 Bucharest, Romania; mjr.virlan@gmail.com (M.J.R.V.); \\ miricescudaniela@yahoo.com (D.M.); radu_radulescu24@yahoo.com (R.R.); \\ alexandratotan@yahoo.com (A.T.); mariagreabu@yahoo.com (M.G.) \\ 2 Agricultural and Biological Engineering Department, Louisiana State University and LSU Ag Center, 149 EB \\ Doran Building, Baton Rouge, LA 70803, USA; CSabliov@agcenter.lsu.edu \\ * Correspondence: bcalenic@yahoo.co.uk; Tel.: +40-755-044-047
}

Academic Editor: Maurizio Battino

Received: 15 December 2015; Accepted: 28 January 2016; Published: 9 February 2016

\begin{abstract}
There is a growing interest in the development of organic nanomaterials for biomedical applications. An increasing number of studies focus on the uses of nanomaterials with organic structure for regeneration of bone, cartilage, skin or dental tissues. Solid evidence has been found for several advantages of using natural or synthetic organic nanostructures in a wide variety of dental fields, from implantology, endodontics, and periodontics, to regenerative dentistry and wound healing. Most of the research is concentrated on nanoforms of chitosan, silk fibroin, synthetic polymers or their combinations, but new nanocomposites are constantly being developed. The present work reviews in detail current research on organic nanoparticles and their potential applications in the dental field.
\end{abstract}

Keywords: nanoparticles; organic; dentistry; polymers; regeneration

\section{Introduction}

In the recent years, engineered nanoparticles have raised substantial interest due to their possible medical applications in vaccination, diagnostic imaging procedures [1], cancer therapy [2] or sustained delivery of drugs [3]. Nanomaterials, i.e., materials with components less than $100 \mathrm{~nm}$ in at least one dimension [4,5], include nanocontainers, nanofilms, nanomembranes, nanoscaffolds or composites that are a combination of these. Nanoparticles have all three external dimensions in the nanoscale and exhibit characteristics distinct from the corresponding bulk material. Biomedicine stands to profit from the use of nanocarriers. Some of the advantages of the nanostructures are: higher colloidal stability, improved dispersibility, and improved surface reactivity. The most important characteristic of nanoparticles continues to be their ability to control delivery of drugs such as small molecule drugs, proteins, and DNA [6,7].

In dentistry, drug-loaded nano-pharmaceuticals have been extensively utilized over the past few years and are studied in almost all dental related fields [8]. A considerable amount of research has been conducted on metallic nanoparticles, but their safety is still under discussion [9-11]. Because biomedical nanoparticles should be nontoxic for cells (either bioinert or biodegradable), and because their use should not cause side effects in other tissues [12], multiple research groups have shifted their focus from metallic to organic nanoparticles, such as chitosan, silk fibroin or other biodegradable polymers, including poly(lactic-co-glycolic) acid (PLGA). PLGA is a copolymer synthesized from two different monomers-lactic and glycolic acids. PLGA can be obtained mainly by 
ring opening polymerization and polycondensation. Hydrolysis, oxidation and enzymatic degradation are the most important mechanisms of PLGA degradation. Chitosan is a linear polysaccharide composed of $\beta$-(1-4)-linked D-glucosamine (deacetylated unit) and N-acetyl-D-glucosamine(acetylated unit) obtained from chitin by partial deacetylation. Enzymatic degradation of chitosan leads to glucosamine which is phosphorylated to glucosamine 6-phosphate, deaminated and izomerized tofructose-6-phosphate which enters glycolysis. Silk fibroin (SF) is a natural polymer obtained by a variety of species including silkworms (the domesticated silkworm Bombyxmori) and spiders. Enzymatic degradation of the molecules results in amino-acids as end products without modifying the $\mathrm{pH}$. Chitosan and silk fibroin are natural materials, while poly(lactic-co-glycolic) acid is a synthetic polymer that has been approved, due to its biocompatibility, by the U.S. Food and Drug Administration and European Medicine Agency [13] (Figure 1). The focus of this paper is to present the recent advances on organic nanomaterials made of natural compounds (chitosan, chitosan composites and silk fibroin) and synthetic materials (PLGA and composites thereof) and their use in dental nanomedicine.

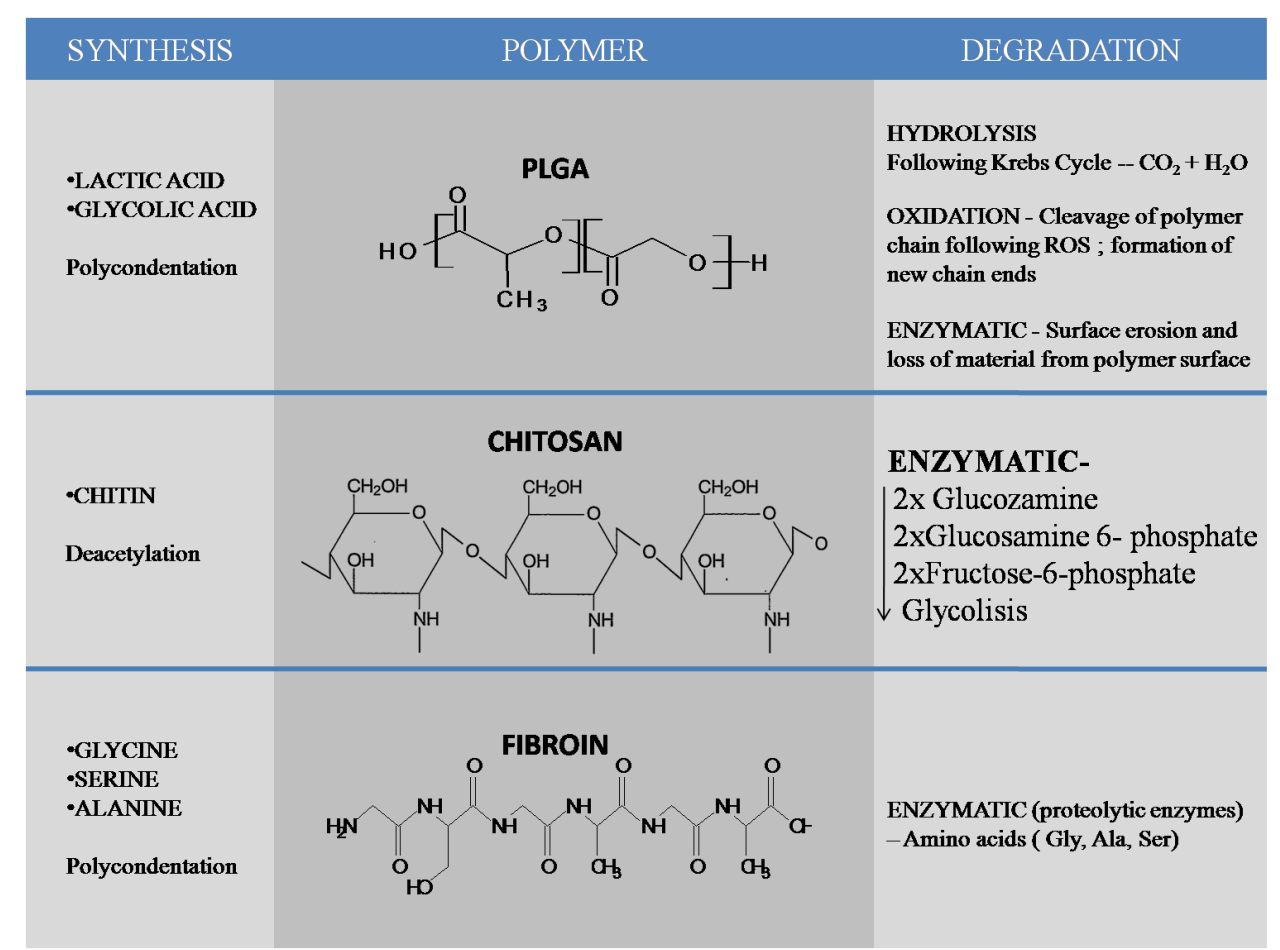

Figure 1. Synthesis and degradation of most important polymers used in formation of nanomaterials most commonly used in the dental field, PLGA, chitosan and silk fibroin

\section{Main Organic Nanomaterials Used in the Dental Field}

\subsection{Natural Organic Nano-Delivery Systems}

Because of their increased biocompatibility, preference for natural products in biomaterial research is increasing. There is an international resurgence of interest in natural products for the development of novel drugs and therapies that could have medical applications [14], some of which are described below. Chitosan is obtained through partial deacetylation from chitin which is a positively charged polysaccahride [15] found in crustaceans [16,17]. It exhibits impressive characteristics for drug delivery applications: biocompatibility, low cost, mucus adhesion, and no immunogenicity or cytotoxicity [18-22]. Silk fibroin, another natural biomaterial, has recently been studied as a substrate for tissue engineered cartilage, bone, ligaments, nerves and also for drug delivery applications. Silk is a naturally occurring polymer material with a high resistance to deformation [23], while silk 
fibroin is a structural protein isolated from silk fibers separated from the cocoons of the silkworm Bobymexmori $[24,25]$.

\subsection{Chitosan Nanoparticles (CNPs)}

In recent years, there has been an increasing interest in using chitosan and chitin for dental medicine applications. A number of studies focused on their controlled delivery properties as well as their ability to support regeneration of oral tissues with applications that span almost all major fields of dentistry: endodontics, periodontics, regenerative dentistry, invasive dentistry or even implantology (Table 1).

Table 1. Applications of chitosan nanoparticles in the oral field.

\begin{tabular}{cccc}
\hline Chitosan Nanosystems & Application & Year & Study \\
\hline Bone morphogenetic protein-2 & Bone regeneration & 2015 & {$[26]$} \\
Bone morphogenetic protein 7 & Bone regeneration & 2015 & {$[27]$} \\
Protein growth factors & Bone regeneration & 2014 & {$[28]$} \\
Dexamethasone & Dentin pulp regeneration & 2015 & {$[29]$} \\
Cetylpyridinium chloride and naf & Dental toothpastes & 2015 & {$[30]$} \\
Chlorhexidinedihydrochloride & Dental toothpastes & 2015 & {$[30]$} \\
\hline
\end{tabular}

Recent work shows that chitosan nanoparticles could be used in new bone formation therapies, leading the way for future applications in implantology, periodontology or dental surgery. Researchers developed bioactive scaffolds containing CNPs incorporated with protein growth factors for bone tissue regeneration $[26,28,31]$, with promising in vivo results. Titanium implants coated with chitosan nanoparticles loaded with biologically active bone morphogenetic protein-2 (BMP-2) managed to induce ectopic bone growth on mice [26]. Recently, a poly( $\varepsilon$-caprolactone) nanofibrous implant functionalized with a chitosan nano-reservoir containing bone morphogenetic protein 7 implanted together with human mesenchymal stem cells resulted in new bone formation and calcification in mice calvarial defects [27]. And interestingly, decorating nanofibers of collagen with protein growth factor loaded chitosan nanocontainers accelerated the speed of bone regeneration in vivo [28]. Moreover, a composite hydrogel containing 2-N,6-O-sulfatedchitosan (26SCS) nanoparticles loaded with bone morphogenetic protein-2 was shown to have profound osteogenic activity, producing mature compact bone associated with new vascular in growth in ectopic bone [32]. This promising result might be due to the fact that 26SCS2-N,6-O-sulfated chitosan(26SCS) promotes the BMP-2 signaling pathway [33], suggesting that 26SCS could be used as the synergistic factor of BMP-2 for bone regeneration. Other data demonstrate that chitosan nanofibers can stimulate osteoblast proliferation and maturation via runt-related transcription factor 2-mediated regulation of osteoblast-associated osteopontin, osteocalcin, and alkaline phosphatase (ALP) gene expression [34]. Researchers observed that mouse osteoblasts grew much better on chitosan nanofiber scaffolds than on chitosan films. Moreover, nanofibers of phosphate functionalized derivatives ofchitosan- $N$-methylene phosphonic chitosan managed to accelerate bone healing by $300 \%$ compared to controls in rabbit tibial defects [35]. A recent study stated that cortical bone allografts coated with chitosan nanofibers could serve as periosteum mimics in bone grafting procedures [36]. Regenerative dentistry can also profit from the CNPs' properties of temporal-controlled release of bioactive molecules [29,37] as they are successfully used in studies concerning dentin pulp regeneration. Bovine serum albumin loaded chitosan nanoparticles were proven to regulate the alkaline phosphatase activity (ALP) in stem cells from apical papilla, while chitosan nanoparticles incorporating dexamethasone have been able to stimulate the differentiation of human dental stem cells from apical papilla into odontoblast-like cells [37].

Minimally invasive dentistry is another field where chitosan nanoparticles could be used to remineralize early enamel caries [38]. A biomimetic remineralizing solution containing nanocomplexes of phosphorylated chitosan and amorphous calcium phosphate led to results similar to fluoride on 
enamel remineralization, but at a higher rate [38]. Its application could also reduce the risks associated with fluoride treatment, such as allergies or fluorosis [39].

Chitosan nanoparticles exhibit antibacterial proprieties mainly because of their polycationic charge, with higher reactivity in nanoform than in bulk [40-43]. This quality has broadened the research of chitosan nanoparticles in dental endodontics, as they can be successfully used in root canal treatments. CNPs possess an inherent antibacterial activity effective against Enterococcus faecalis [44], a property that is not diminished in the presence of dentin or lipopolysaccharides [41]. Moreover, incorporation of chitosan nanoparticles into root canal sealers has the potential benefits of inhibiting microbial penetration and reduced biofilm formation at the dentin-root filling interface $[45,46]$. Consequently, several endondotic sealers have been developed by incorporating chitosan nanoparticles into zinc-oxide-eugenol [47], epoxy resin or calcium silicate-based sealers [45], with each presenting enhanced antibacterial qualities. However, in a recent study, resin-based dental sealants modified with nylon- 6 and chitosan nanofibers were prepared in an attempt to provide an antibacterial effect, but none of the chitosan-containing sealants displayed antimicrobial proprieties [48]. Also, chitosan nanoparticles showed a higher reduction of Enterococcusfaecalis biofilms as compared to calcium hydroxide, but bacteria still survived even after a $24 \mathrm{~h}$ treatment with $20 \mathrm{mg} / \mathrm{mL}$ chitosan nanoparticles [43]. It should also be noted that some researchers are not sure whether the inhibition of bacterial adherence by the chitosan nanoparticles is caused by killing the bacteria in their vicinity or by the nanoparticles' direct effect on the bacteria-substrate interaction [47].

In the future, chitosan nanoparticles could be integrated into toothpastes or even used in dental prophylactic therapies aimed at reducing bacterial biofilms in the oral cavity. CNPs have already been developed that are loaded with toothpaste active compounds [30,49]. The in vitro toxicity of the chitosan nanoparticles on human gingival fibroblasts was considered moderate after $24 \mathrm{~h}$ exposure [30]. In addition, one study found that nanoparticle complexes prepared from low molecular weight chitosan showed a high antimicrobial effect on Streptococcus mutans biofilms [50]. CNPs were active at a neutralpH and resulted in damage to more than $95 \%$ of the S.mutans cells [50]. Because Streptococcus mutans is one of the most intensively studied cariogenic microorganisms associated with caries progression in humans [51,52], killing this bacterium could be an effective form of preventive dentistry.

Chitosan nanofibers, nanopowders and nanoparticles also showed promising results in other applications connected to the dental field, such as nerve regeneration medicine [53] or healing skin $[54,55]$ and oral mucosa [56]. A chitosan-based nanofibrous material was tested as a wound dressing material for IIIIa and IIIb degree burns and managed to protect the site from infection while also supporting skin regeneration [55]. Recently, a scaffold with a surface layer consisting of chitosan nanofibers was developed as a potential skin substitute [54].

The possible applications of CNPs in anticancer treatment should also be noted. Chitosan nanoparticles have been successfully incorporated into systems involving active targeting, controlled drug delivery, or imaging of cancer cells [57-61]. Methotrexate-charged chitosan nanoparticles have been formulated, and their utilization induced a greater increase of the apoptosis of tumour cells than treatment with the free drug [61]. Also, methotrexate CNPs exhibited relative selectivity for cancer cells, as the cytotoxic effects were significantly lower in the non-tumor control cells HaCaT (human keratinocytes immortalized) [61]. As methotrexate is a major chemotherapeutic used in the treatment of the head and neck cancers [62], CNPs loaded with anticancer drugs could be used in the future for oral cancer treatment. Interestingly, nanoparticles with surfaces decorated with chitosan that can specifically target theCD44receptors in cancer stem-like cells have recently been fabricated [63]. The CD44 receptor protein is found to be overexpressed by many tumors and is identified as one of the most common cancer stem cell surface markers in tumors including head and neck cancer $[64,65]$. Considering the fact that cancer stem cells in oral squamous carcinoma show high expression of CD44 [66], some might consider in the future the hypothesis that CNPs could be used for selective oral 
cancer stem cell targeting. However this hypothesis needs further testing in order to clearly show that CNP might be selective towards CD44 positive cells.

Chitosan nanoparticles applications in regenerative medicine as well as in regenerative dentistry is clearly an intensively studied field. Taking into account the high number of in vitro, but also in vivo presented studies, a next logical step should be the development of novel CNPs uses in dentistry as well as the beginning of future clinical trials.

\subsection{Composite Chitosan Nanoparticles}

Because chitosan nanoparticles exhibit several disadvantages, such as poor mechanical and processing properties or insolubility in common organic solvents [67], researchers have attempted to combine them with an impressive number of polymeric or inorganic or other organic substances. Table 2 briefly presents the main composite chitosan nanostructures that have been fabricated in recent years and could have potential uses in dentistry. Composite materials blend the advantages of chitosan with the added substance, and their nanosized presentation has shown desirable characteristics in biomedical applications. However, their uses are limited to bone regeneration and wound healing acceleration, with very few focusing on antibacterial treatments.

Because natural polymers exhibit similarities to the extracellular matrix, special attention is given to chitosan-based materials for bone tissue engineering application. Chitosan-gold nanoparticles managed to enhance osseointegration of dental implants [68-70] incorporated with the transcription factor c-myb or with the anti-inflammatory molecule peroxisome proliferator activated receptor gamma (PPAR). Interestingly, chitosan-gold nanoparticles conjugated with PPAR were used to modify dental implants in vitro, but also in vivo in rat mandible. The modified implants led to newly-formed bone with enhanced mineral density and reduced inflammation, and as such, may have future uses as a dental prosthetic material in patients suffering from inflammatory diseases like arthritis, diabetes and osteoporosis. Since the anti-inflammatory effect of peroxisome proliferator activated receptor gamma has been demonstrated in periodontitis [71,72], in human dental pulp cells [73,74] and in mouse osteoblast precursor cells [75], chitosan-gold nanoparticles incorporated with PPAR gamma could be tested in the future also for periodontal or pulpal regeneration.

Other composite chitosan nanoparticles have also been developed for bone tissue engineering. Recent studies focused on bone regeneration that could be supported by poly( $\varepsilon$-caprolactone) (PCL) nanofiber scaffolds containing chitosan nanoparticles or by chitosan-PCL nanofibers [76,77]. Scaffolds fabricated from poly( $\varepsilon$-caprolactone) (PCL) nanofibers and chitosan-PCL copolymers showed that the polymer is biocompatible with bone cells such as MG63 cells [76,78]. Moreover, nanofiber matrices of polycaprolactone-chitosan functionalized with collagen I led to higher alkaline phosphatase (ALP) activity and mineralization of rat bone marrow-derived stromal cells [77]. Also, nanoparticles prepared by combining chitosan, tripolyphosphate and chondroitin sulfate could be used to slowly release osteogenic proteins, such as Nel-like molecule-1 [79], in future bone graft applications.

An important bioactive molecule in guided bone regeneration is hydroxyapatite, and consequently, several composite hydroxyapatite-containing nanomaterials have been developed: composite chitosan/hydroxyapatite nanofibers [15,80,81], chitin hydrogel/ nanohydroxyapatite nanocomposite scaffolds [82], chitosan/polyvinyl alcohol/nanohydroxyapatite nanoscaffolds [83], and hydroxyapatite/ collagen/ chitosan nanocomposite fibers [84]. Further, biocomposite nanofibrous scaffolds have been fabricated from poly(3-hydroxybutyrate-co-3-hydroxyvalerate), chitosan and hydroxyapatite for mineral deposition [85]. In the case of the latter, chitosan provided cell recognition sites, while hydroxyapatite acted as a chelating agent for organizing the apatite-like mineralization [85]. Interestingly, biocompatible coatings of cellulose acetate nanofibers and composites of hydroxyapatite nanoparticles and chitosan led to the formation of a bone-like apatite layer on the implants with such coverings [86]. One study found that hydroxyapatite mineralized on chitosan-coated poly(lactic acid) nanofiber composites could mimic structural, compositional, and biological functions of native bone [87]. 
Table 2. Main applications of composite chitosan nanosystems in the oral cavity.

\begin{tabular}{|c|c|c|c|}
\hline Chitosan Composites & Dental Field & Year & Study \\
\hline Chitosan-gold nanoparticles & implantology & 2015 & [70] \\
\hline chitosan-poly( $\varepsilon$-caprolactone) nanofibers & bone regeneration & 2015 & [76] \\
\hline chitosan, tripolyphosphate and chondroitin sulfatenanoparticles & bone regeneration & 2012 & {$[75]$} \\
\hline composite chitosan/hydroxyapatite nanofibers & bone regeneration & 2008 & {$[80]$} \\
\hline chitin hydrogel/nanohydroxyapatitenanocomposite scaffold & bone regeneration & 2011 & [82] \\
\hline chitosan/polyvinyl alcohol/nanohydroxyapatitenanoscaffolds & bone regeneration & 2008 & {$[83]$} \\
\hline hydroxyapatite/collagen/chitosan nanocomposite fibers & bone regeneration & 2010 & [84] \\
\hline poly-3-hydroxybutyrate-co-3-hydroxyvalerate/chitosan/hydroxyapatite nanofibrous scaffold & bone regeneration & 2015 & [85] \\
\hline chitosan/polyethylene oxide nanofibers & cartilage tissue engineering & 2005 & [88] \\
\hline chitosan/polyvinyl alcohol nanofibers & oral candidiasis & 2015 & [89] \\
\hline poly(E-caprolactone)-poly(ethylene glycol) copolymernanofibrous mats incorporated into chitosan & regeneration of periodontium & 2015 & [90] \\
\hline chitosan/polyethylene oxide nanofibers & wound healing & 2014 & [91] \\
\hline poly( $\varepsilon$-caprolactone)/chitosan nanofibers & wound healing & 2014 & [92] \\
\hline chitosan/polyvinyl alcohol nanofibers & wound healing & 2015 & [93] \\
\hline chitosan/collagen nanofibrous membranes & wound healing & 2006 & [94] \\
\hline chitosan hydrogel/nanofibrin composite & wound healing & 2012 & [95] \\
\hline chitosan/sericin nanofibers & & 2014 & [96] \\
\hline chitosan-Eudragit nanofibrous sheets & & 2015 & [97] \\
\hline tannic acid/chitosan/pullulan composite nanofibers & & 2015 & [100] \\
\hline chitosan-rose bengal nanoparticles & & 2014 & [101] \\
\hline
\end{tabular}


There is also a high number of research papers that have developed composite chitosan-containing nanofibers for other biomedical applications: nanofibers of chitosan/polyethylene oxide for cartilage tissue engineering [88], chitosan/polyvinyl alcohol nanofibers for oral candidiasis treatment [89,102] and poly(e-caprolactone)-poly(ethylene glycol) copolymer nanofibrous mats that were incorporated into chitosan for the regeneration of periodontium [90]. An interesting multitude of nanocomposite materials have been fabricated for wound healing applications: chitosan/polyethylene oxide nanofibers [91,103], poly( $\varepsilon$-caprolactone)/chitosan nanofibers [92,104,105], chitosan/polyvinyl alcohol nanofibers [93,106,107], chitosan/collagen nanofibrous membranes [94], chitosan hydrogel/nanofibrin composite [95], chitosan/sericin-nanofibers [96], chitosan-Eudragit nanofibrous sheets [97], chitosan/arginine nanofibrous membrane [98], chitosan/gelatin/shape memory polyurethane nanofibers [99] or tannic acid/chitosan/pullulan composite nanofibers [100].

Different studies reported on using CNP antibiotic qualities in odontotherapy $[40,108]$, but this functionality is questionable, as some authors have stated that the pulpal tissue has a strong inhibitory effect on CNP antibacterial characteristics. Composite chitosan nanoparticles have been fabricated because of their enhanced antibacterial property, which is important in anti-cavities therapy or endodontic procedures. One study developed a nanosized compound which contains silver nanoparticles, chitosan and fluoride, which seems to be a promising anti-cavities agent with low toxicity to living cells [109]. Several chitosan nanoparticles, nanofilms or nanofibers have been also incorporated with silver in order to enhance the antibacterial activity of the nanocomposites [110-113]. Researchers developed photoactivated Rose Bengal-functionalized chitosan nanocarriers that were effective in killing Enterococcu sfaecalis biofilms [101,114,115], as well as in neutralizing lipopolysaccharides obtained from Pseudomonas aeruginosa while also stabilizing dentin-collagen. Taking into account that $E$. faecalis and P. aeruginosa are associated with endodontic infections [116], their killing would be beneficial in dental endodontic treatments.

This multitude of available research papers supports the idea that chitosan nanoparticles are one of the most studied organic nanosystems in the dental field. Nanocomposite CNPs development is significant because of their improved properties, mostly in guided bone regeneration procedures or in dental therapies where the ability to accurately kill bacteria is necessary. Following this trend, it is expected that the development of new composite chitosan nanoparticles will rise even further in the following years.

\subsection{Silk Fibroin Nanoparticles}

Silk fibroin nanoparticles have been used in a multitude of medical applications (Table 3), mainly in regenerative medicine, because of their controlled delivery properties [117]. Silk fibroin can be modified by adding different functional groups. Functionalization allows for an adjustable drug release system with distinct interactions between drug and nanocarrier and varied releasing kinetics. The kinetics are also dependent on silk fibroin's large molecular weight, hydrophobicity and crystalline structure. Details on the chemistry, structure and delivery properties of silk fibroin can be found elsewhere [118]. Nanosystems made from silk fibroin showed encouraging results in studies addressing regeneration of tissues found in the oro-maxillo-facial field, such as bone, skin or vascular tissues. Although not the main focus of regenerative dentistry, wound healing and vascular tissue formation are also important for the dentist, considering the frequency of oral mucosa wounds found in everyday practice. Silk fibroin nanoparticles could have numerous applications in dentistry, but mainly in bone regeneration procedures, where they have been used in the form of nanospheres, nanofibrous membranes, or nanofibrous scaffolds [117]. New bone formation is needed in dental surgeries such as implant therapy or in some periodontal treatments. Studies found that experimental nanofibrous electrospun silk scaffolds incorporated with bone morphogenetic protein-2 supported human mesenchymal stem cells osteogenic differentiation [119]. Silk fibroin nanofiber membranes were implanted in calvarial defects of rabbits and resulted in complete healing with new bone after 12 weeks [120]. Also, silk fibroin nanospheres were applied in the manufacture process of 
vaterite-microparticles, which could be further used as drug carriers in bone tissue engineering [121]. Moreover, composite nanostructures of silk fibroin and chitosan were developed, combining the advantages of both organic materials. Nanofibrous membrane scaffolds of chitosan and silk fibroin led to osteogenic differentiation of human mesenchymal stem cells, as was demonstrated by the increased alkaline phosphatase activity and expression of the osteogenic marker genes [122]. In a recent animal study, nanohydroxyapatite was added to the chitosan/silk fibroin nanofibrous membrane, thereby facilitating the osteogenesis of human mesenchymal stem cells [123]. Also recently, a thin nanofibrous membrane containing silk fibroin/chitosan/ nanohydroxyapatite/ bone morphogenetic protein-2,subcutaneously implanted together with human mesenchymal stem cells, resulted in ectopic bone formation in vivo [124]. Wound healing in the oral cavity would suggest a wound dressing material which is possible to contain silk fibroin nanosystems. Hybrid or blend chitin/silk fibroin nanofibers could be effective as wound-healing accelerators in tissue regeneration [125]. The chitin/silk fibroin blend nanofibrous matrix, containing $75 \%$ chitin and $25 \% \mathrm{SF}$, has been shown to promote excellent cell attachment and spreading for human keratinocytes and fibroblasts [126]. It is important to note that pure silk fibroin nanofibers led to enhanced spreading of human epidermal keratinocytes than the pure chitin nanofibers. In order to improve the antibacterial proprieties of the wound dressing materials, one experiment developed nanofibrous membranes of chitosan and silk fibroin effective against E. coli, a gram negative bacteria [127]. The potential of silk fibroin nanofibers to form vascular tissues should also be noted. Nanofibers of silk fibroin and chitosan managed to support human umbilical vein endothelial cells into forming capillary-like vascular structures and could be used to regenerate vascular tissue [128]. Although there are no specific studies on silk fibroin nanoparticles use in oral cancer, silk fibroin nanoparticles can deliver drugs and genes to the tumorigenic cells [129,130]. Nanocarriers of silk fibroin loaded with the antitumor drug cisplatin were able to efficiently deliver the drug to cancer cells while avoiding the cytotoxicity and side effects of the free drug on normal tissues [130]. Considering all this, it may be possible to speculate that silk fibroin nanoparticles could have future applications in the field of oral cancer treatment. While in vitro experimental procedures have shown very promising results, future studies are needed for assessing silk fibroin nanoparticles properties in animal studies. Silk fibroin is an attractive biomaterial for tissue engineering and controlled delivery of molecules but as in the case of chitosan several challenges remain. As natural products their characteristics may vary between individuals and species. To date, in the dentistry, the main focus of silk fibroin drug delivery systems has been on bone regeneration applications and wound healing products.

Table 3. Applications of silk fibroin nanoparticles in dentistry.

\begin{tabular}{|c|c|c|c|}
\hline Nanoparticle Type & Dental Field & Type of Study & Study \\
\hline silk fibroin nanofiber membranes & bone tissue engineering & in vivo & [120] \\
\hline silk fibroin nanofibrouselectrospun scaffolds & bone tissue engineering & in vitro & [119] \\
\hline silk fibroin/chitosan nanofibers & bone tissue engineering & in vitro & [122] \\
\hline silk fibroin/chitosan/nanohydroxyapatite nanofibrous membrane scaffolds & bone tissue engineering & in vivo & [123] \\
\hline silk fibroin/chitosan/nanohydroxyapatite nanofibrous membrane & bone tissue engineering & in vivo & {$[124]$} \\
\hline silk fibroin/chitin blend fibers & wound healing accelerator & in vitro & {$[125]$} \\
\hline silk fibroin and chitosan nanofibrous membranes & wound healing accelerator & in vitro & [127] \\
\hline silk fibroin and chitosan nanofibers & vascular tissue regeneration & in vitro & [128] \\
\hline
\end{tabular}

\section{Synthetic Organic Nano-Delivery Systems}

Full exploitation of the natural materials has been limited because of the batch-to-batch variations in their properties [131]. On the other hand, manufacturing of synthetic polymers has the flexibility and reproducibility desired for nanomedical applications [132]. In dental medicine, one of the most studied synthetic organic molecule is poly-lactic-co-glycolic acid co-polymer. PLGA is highly compatible and has been approved by the U.S. Food and Drug Administration for the use of drug delivery, diagnostics and other medical applications. Most importantly, PLGA is biodegradable; its degradation leads to carbon dioxide and water [133]. 


\subsection{PLGA Nanoparticles}

The number of studies published on PLGA nanoparticles (NPs) application in dentistry has grown in recent years [8]. Recently, a wide variety of studies has been undertaken leading the way for possible future applications of PLGA NPs in a high number of dental fields, from periodontology [134] and endodontics [135] to tissue regeneration of skin [136-138], bone [139], or cartilage [140-144] (Table 4).

Table 4. Applications of PLGA nanoparticles in the dental field.

\begin{tabular}{cccc}
\hline Active Substance & Dental Field & Year & Study \\
\hline photosensitizer methylene blue & endodontics & 2010 & {$[135]$} \\
antibiotic minocycline & periodontics & 2012 & {$[134]$} \\
parathyroid hormone & bone regeneration & 2015 & {$[139]$} \\
recombinant human bone morphogenetic protein-7 & bone regeneration & 2007 & {$[145]$} \\
nafcillin & osteomyelitis treatment & 2008 & {$[146]$} \\
simvastatin & osteoporosis treatment & 2015 & {$[147]$} \\
lovastatin & healing of fractures & 2007 & {$[148]$} \\
LL37 (a human host defense peptide) & wound healing & 2014 & {$[137]$} \\
curcumin & wound healing & 2013 & {$[136]$} \\
vascular endothelial growth factor & wound healing & 2015 & {$[138]$} \\
dexamethasone & gingival fibroblast differentiation & 2015 & {$[149]$} \\
amphotericin B & fungal infections treatment & 2015 & {$[150]$} \\
chondrogenesis related proteins & chondrogenesis & 2014 & {$[142]$} \\
Genes SOX 5, SOX 6, SOX 9 & chondrogenesis & 2011 & {$[140]$} \\
\hline
\end{tabular}

The most important studies that focus on PLGA NPs and their uses in the dental field are described below. PLGA nanoparticles loaded with the photosensitizer methylene blue exhibited significant killing of Enterococcus faecalis biofilm species in experimentally infected root canals of extracted human teeth [135]. These results are promising, considering that Enterococcus faecalis is highly associated with endodontic treatment failure [151,152]. Moreover, encapsulation of the antibiotic mynocycline into PLGA nanoparticles proved to be remarkably more effective than the free drug against Aggregatibacter actinomycetemcomitans [134], another etiologic agent of periodontal diseases [153-155]. Another research direction with potential clinical applications is the use of PLGA to support new bone formation [156-161] and/or osteogenic differentiation [162]. PLGA NPs encapsulated with recombinant human bone morphogenetic protein-7 in a nanoporouspoly(L-lactic acid) scaffold induced bone healing in rats [145]. Additionally, nanocarriers consisting of PLGA and incorporating bioactive molecules nafcillin [146] or simvastatin [147] were studied for osteomyelitis and osteoporosis treatment, respectively .PLGA NPs could also be utilized in fracture treatment, as one study found that lovastatin-containing PLGA nanosystems increased the rate of healing of femoral fractures [148]. Interestingly, nanosized PLGA had positive results in experiments concerning wound healing applications [136-138]. LL37(a human host defense peptide) encapsulated in PLGA nanoparticles led to nearly complete wound closure in mice by day 13 due to the sustained release of both LL37 and lactate. Similarly, curcumin and vascular endothelial growth factor in PLGA nanostructures promoted re-epithelization or healing of non-diabetic and diabetic wounds. Cartilage regeneration might be a promising novel approach for treating articular fractures or disorders of the temporo-mandibular joint. Numerous experiments obtained chondrogenesis of human mesenchymal stem cells by exposing cells to PLGA NPs that incorporated chondrogenesis-related proteins, transcription factors, or genes. Of interest also is the fact that PLGA nanocarriers have been developed to deliver active molecules for other possible dental-related applications: transport of dexamethasone for gingival fibroblasts differentiation [149] or controlled release of amphotericin B for fighting against fungal infections [150]. Novel skin cancer treatments could include PLGA NPs [163] transporting small molecules, RNA or genes in order to target the p53 inactivation or the epidermal growth factor receptor over-expression in skin squamous carcinoma tumors [164].Taking into account the numerous experiments involving PLGA and PLGA-derived nanoparticles used for diagnosis or 
treatment of other types of tumors [13,165-168], an increase in research regarding PLGA nanoparticles uses in the oral cancer field is expected.

\subsection{Composite PLGA Nanoparticles}

PLGA materials are also easy to fabricate and combine with a wide variety of natural or synthetic molecules in different shapes and structures (nanofibers, nanocontainers or nanoscaffolds). Interestingly, PLGA and chitosan are some of the most studied organic polymers in dentistry. Because of chitosan's biocompatibility, the PLGA-chitosan combination in biomedical nanostructures creates promising applications in prophylactic dentistry [30] or wound healing [169,170]. Chitosan and chitosan-covered PLGA nanoparticles could be integrated in dental toothpaste, as indicated by one study where nanoparticles were loaded with chlorhexidinedihydrochloride [30]. The release of the active molecules from chitosan NPs was dependent on the $\mathrm{pH}$ of the medium, while PLGA nanocarriers' release of chlorhexidine was less $\mathrm{pH}$-dependent [30]. Moreover, PLGA/chitosan nanofibers promote the fibroblasts' attachment and proliferation and could therefore be used in skin tissue engineering, while their functionalization with graphene oxide and silver nanoparticles creates a biomaterial with antimicrobial proprieties against both Gram-negative (Escherichia coli and Pseudomonas aeruginosa) and Gram-positive (Staphylococcus aureus) bacteria [171].

Although PLGA nanofibers are widely used in the manufacture of scaffolds for tissue regeneration [171] and despite their biocompatibility, the clinical applications of pure PLGA for bone regeneration are hampered by its poor osteoconductivity [172,173]. Therefore, a variety of composite PLGA scaffolds have been developed for bone tissue engineering (Table 5). Different nanosized PLGA composite systems have been successful at inducing osteogenic differentiation of stem cells: PLGA/collagen nanofibers with calcium phosphate [174], PLGA/ poly(3-hydroxybutyrate-co-3-hydroxyvalerate) nanoparticles [175], nanoparticles of bis(poly(lacticco-glycolic acid)-phenylalanine-polyethylene glycol-quaternary ammonium grafted diethyltriaminbis (PLGA-phe-PEG)-qDETA) [176], and even PLGA-hyaluronic acid copolymer nanoparticles [177]. Some of these composite nanostructures, such as PLGA/collagen/calcium phosphate nanomembrane [174], managed to support osteogenic differentiation on their own, while others were incorporated with simvastatin [176] or growth factors like bone morphogenetic protein-2 [178], BMP-2 and BMP-7 [45], bone morphogenetic protein-2 and insulin-like growth factor-1 [177]. Interestingly, although the mechanism is not fully understood, the bis(PLGA-phe-PEG)-qDETA nanoparticles alone were able to promote the osteogenesis of the bone marrow mesenchymal stem cells, possibly by enhancing the expression of osteocalcin that leads to elevated alkaline phosphatase (ALP) expression and mineralization [177].

Table 5. Main applications of composite PLGA nanosystems in dental medicine.

\begin{tabular}{|c|c|c|c|}
\hline PLGA Composite Nanosytems & Dental Field & Year & Study \\
\hline PLGA nanoparticles covered with chitosan & dental toothpastes & 2015 & {$[30]$} \\
\hline PLGA/chitosan nanofibers & wound regeneration & 2014 & [170] \\
\hline Calcium phosphate/collagen/PLGA nanofibers & bone regeneration & 2011 & [174] \\
\hline $\begin{array}{c}\text { PLGA/poly(3-hydroxybutyrate- } \\
\text { co-3-hydroxyvalerate) nanoparticles } \\
\text { bis(poly(lactic-co-glycolic }\end{array}$ & bone regeneration & 2010 & [175] \\
\hline $\begin{array}{l}\text { acid)-phenylalanine-polyethylene glycol-quaternary } \\
\text { ammonium grafteddiethyltriamin nanoparticles }\end{array}$ & bone regeneration & 2014 & [176] \\
\hline PLGA-HA copolymer nanoparticles & bone regeneration & 2014 & [177] \\
\hline PLGA/polycaprolactonenanoparticles & bone regeneration & 2015 & [178] \\
\hline $\begin{array}{l}\text { heparin-fibrin-poly(lactide-co- } \\
\text { caprolactone) nanoparticles }\end{array}$ & chondrogenic differentiation & 2009 & [179] \\
\hline PLGA nanoparticlescovered with hyaluronic acid & osteogenic differentiation & 2015 & [180] \\
\hline
\end{tabular}

There is also one in vivo study that used polycaprolactone/PLGA injectable nanoparticles containing recombinant human BMP-2 in rabbits [178]. The results were very positive, 
with $78 \%$ trabecular bone formation with surrounding fibro-vascular tissues within 6 weeks. Future treatments of joints or articular structures may be based on cartilage regeneration. Heparin-fibrin-poly(lactide-co-caprolactone) nanoparticle complex releasing transforming growth factor beta 1 sustained chondrogenic differentiation of human adipose derived stem cells [179], while hyaluronic acid-covered PLGA nanoparticlescould have future applications in chondrogenic, osteogenic or adipogenic new tissue formation [180].

\subsection{Dendrimers, Lipid Nanoparticles and Liposome Applications in the Dental Field}

Dendrimers are highly branched, synthetic polymers with micelle-like behavior demonstrating promising results in several biomedical applications. Their properties make them suitable as scaffolds for tissue repair, targeted carriers for antiviral or chemotherapeutic drugs, gene delivery systems, and as ligands for various medical applications [181,182]. Dental applications of dendrimers are currently limited and research in the field demonstrates conflicting results depending on the dental field in which the particle have been used and on the polymer choice. Reports show that dendrimers may be used as releasing-scaffolds for releasing anti-periodontopathogenic agents [183]; implant surface coating with phosphoserine and polylysine-dendrimers do not improve their osteointegration [184] while other studies report that they can promote osteoblast differentiation [185]; poly-amidoamine-dendrimer molecules have anti-adhesive properties and modulate the oral bacterial response [186]; dentine surface coating with poly-amidoamine-dendrimers can induce hydroxidapatite formation and thus contribute to dentinal tube occlusion [187-189].

Solid lipid nanoparticles are a valuable drug carrier systems, representing a solid alternative to carriers such as micro-/nanoparticles or liposomes. These particles have several attributes that make them attractive as drug delivery systems: physically stable system; small size (typically from 50 to $100 \mathrm{~nm}$ ); high drug loading; large surface area when compared to their size; low toxicity, improved delivery of lipophilic active compounds. However their usage in the medical field is limited by several shortcomings such as: systems have a tendency to gelate over time resulting in expulsion of the drug and an increase in size over time [190]. There are very few studies that focus on the interaction between these nanoparticles and the biology of oral cavity. To date potential applications of lipid nanoparticles in the oral field such as in the treatment of periodontal diseases, are lacking.

Liposomes are spherical vesicles with a diameter ranging from $20 \mathrm{~nm}$ to several micrometres, consisting of one or more lipid bilayers surrounding aqueous spaces [191]. They are made from natural lipid molecules, mainly phospholipids [191] and are considered to be non-toxic, non-immunogenic and biodegradable [192,193]. Liposomes are one of the most employed nanodevices to encapsulate antibiotics for treating intracellular infections [194] and therefore, could have promising applications in periodontology. Numerous research groups have fabricated antibiotic incorporating liposomes for use against various periodontal pathogens including liposomes containing metronidazole against Streptococcus mutans [195], chlorhexidine and triclosan for Streptococcus oralis [196], triclosan against Streptococcus sanguis [197] or for Pseudomonasaeruginosa, as well as amikacin and gentamicin-containing nanoliposomes [198].Similarly, the combination of liposomes and photodynamic therapy was proven effective against Porphyromonasgingivalis [199]. In addition liposomes incorporating bovine lactoferrin (LbLF)could be used for periodotal prevention in patients undergoing orthodontic treatments [200]. Recent in vivo studies suggested that liposomes significantly inhibited lypopolysacharide induced bone resorption but not orthodontic force induced bone remodeling. Similarly, scaling and root planing with subgingival application of liposome-encapsulated SOD managed to suppress periodontal inflammation on experimentally induced periodontitis in beagle dogs, after only 6 weeks of treatment [200]. Moreover, liposomal phosphatidylserine inhibits osteoclastogenesis and adjuvant arthritis-induced trabecular bone loss in rats, by generating TGF- $\beta 1$ and PGE 2 [201].Another characteristic with implications in the dental field is the ability of liposomes to target macrophages naturally. Thus mynocycline hydrochloride nanoliposomes could provide a long term therapeutic effect in targeted, controlled release topical periodontitis therapy, they could inhibit the proliferation of murine 
macrophages (ANA-1), and specifically achieve anti-inflammatory effects by suppression of TNF- $\alpha$ mRNA expression. Furthermore, liposomes were able to deliver plasmid DNA into the gingiva and could have future applications in periodontal genetic therapies [202]. However, these nanostructures are not considered very stable, especially the larger size liposomes [203] and that is a significant drawback of liposome use in dental applications.

Among all nanomaterials presented in this review, some have the potential of being translated to clinical situations more than others. For example, one promising application for PLGA nanoparticles that could develop into a commercial application is described by Sadat et al. [134]. The PLGA nanoparticles are reported to release minocycline over a 5-day period, suggesting that this nanosystem can be ideal for treatment of periodontal diseases. Similarly, the use of PLGA nanoparticles loaded with the photosensitizer methylene blue showed bactericidal effects on biofilm species in infected root canals of human teeth and may have promising results in antimicrobial endodotic treatment [135]. Both chitosan and silk fibroin based nanoparticles have been shown to efficiently encapsulate and deliver antitumor drugs. However the reviewed literature shows that in dentistry these two polymers are more suitable for applications focusing on tissue engineering (especially bone formation), formation of vascular tissue and wound healing (Tables 2 and 3).

\section{Conclusions}

In the light of the above studies, the application of nanotechnology-based dentistry stands to profit greatly from the development of organic-based materials. A variety of shapes and structures, from nanomembranes, nanopowders and nanofibers to nanoscaffolds or nanogels can be fabricated from organic materials. While liposomes, solid lipid and dendrimers have been developed to address oral disease treatment, polymeric nanoparticles made of PLGA, chitosan and silk fibroin appear to be some of the most studied nanomaterials in dentistry.

Nanostructures fabricated from these materials support regeneration of oral tissues, covering all main dental fields from periodontology and endodontics to bone healing. The available literature shows that, to date, PLGA is the most used polymer for NPs in dentistry. Its properties make it especially suitable as a reliable drug delivery system, but so far there is no general consensus on the benefits of PLGA nanoparticles when used alone in bone regeneration therapies. Moreover, surface coating with these polymeric NPs can have little or no effect on the dental implant osteintegration. One concern is related to the fact that several oral bacteria have good adherence on PLGA which can potentially lead to infections for in vivo applications. Chitosan and silk fibroin are more often selected for oral tissue engineering. Chitosan is recognized for its mucoadhesivity and the property of improving active compounds' penetration across mucosal surfaces, while also supporting cellular adhesion, mobility and proliferation. In an increasing trend, composite nanostructures are being developed, combining advantages of all individual incorporated materials. Chitosan nanoparticles are easily combined with other substances, conferring or improving antimicrobial and antifungal proprieties to a variety of nanostructures. Additionally, silk fibroin nanoparticles, due to their controlled delivery properties, exhibit promising results in studies for formation of oral bone or vascular tissue.

Several limitations of polymeric nanoparticle use in dentistry are noted. PLGA is a co-polymer that can be degraded by hydrolysis to the two initial acids and, unlike chitosan or silk fibroin, can alter the $\mathrm{pH}$ at the delivery site, affecting the surrounding tissue as well as the effectiveness of the delivered drug. Other pitfalls related to PLGA-based NPs, include their relative poor loading of the active compound coupled with a high release burst of the drug. Overall, poor drug loading efficiency seems to be the major issue for PLGA NPs and can limit the use of these particles in clinical trials. Biomacromolecules' instability inside polymeric particles is another important issue to consider. It has been reported that the structure of fragile molecules such as DNA, RNA or proteins can be destabilized or degraded during drug entrapment. A significant limitation of natural components chitosan and silk fibroin is variations in their properties as a result of vendor-dependent extraction and purification 
methods. Another limitation of organic NPs in general, is the relatively insufficient data on their interaction and impact on the oral environment. For all types of nanoparticles described in this review more data is needed in order to fully understand the interaction of these nanocarriers with cells and tissue and to assess their toxic potential. While most in vitro and animal model studies report encouraging results, clinical trials are needed in order to correctly assess NPs toxicity in vivo.

The field of organic composites used for controlled delivery of antibiotics, growth factors or even anticancer substances continues to grow. Based on the positive data obtained in vivo and in vitro, further studies are needed in order to translate the knowledge obtained in the research lab to the daily clinical dental practice.

Acknowledgments: M.J.R.V. acknowledges that this paper is partially supported by the Sectorial Operational Programme Human Resources Development (SOP HRD), financed from the European Social Fund and by the Romanian Government under the contract number SOP HRD/159/1.5/S/135760. D.M. would like to thank for the Young Scientist Grant 2014-2016 received from University of Medicine and Pharmacy Carol Davila, Bucharest, Romania. B.C.acknowledges that this work was supported by a grant of the Romanian National Authority for Scientific Research and Innovation, CNCS-UEFISCDI, project number PN-II-RU-TE-2014-4-1879. C.M.S and B.C. would also like to thank for the Senior Fulbright Grant 2015-2016 received from the Romanian-US Fulbright Commission. The authors would like to thank Kurt Ristroph for carefully proofreading the manuscript.

Author Contributions: Maria Justina Roxana Virlan, Daniela Miricescu, Radu Radulescu and Alexandra Totan participated in gathering the relevant literature and drafting the manuscript; Cristina M. Sabliov, Bogdan Calenic and Maria Greabu contributed to manuscript design, critically reviewing the manuscript and completion of images and tables. All authors thoroughly read and approved the final manuscript.

Conflict of Interests: The authors declare no conflict of interests.

\section{References}

1. Boraschi, D.; Italiani, P. From antigen delivery system to adjuvanticy: The board application of nanoparticles in vaccinology. Vaccines 2015, 3, 930-939. [CrossRef] [PubMed]

2. Brannon-Peppas, L.; Blanchette, J.O. Nanoparticle and targeted systems for cancer therapy. Adv. Drug Deliv. Rev. 2012, 64, 206-212. [CrossRef]

3. Parveen, S.; Misra, R.; Sahoo, S.K. Nanoparticles: A boon to drug delivery, therapeutics, diagnostics and imaging. Nanomed. Nanotechnol. Biol. Med. 2012, 8, 147-166. [CrossRef] [PubMed]

4. Kong, L.X.; Peng, Z.; Li, S.D.; Bartold, P.M. Nanotechnology and its role in the management of periodontal diseases. Periodontology 2006, 40, 184-196. [CrossRef] [PubMed]

5. Narang, R.S.; Narang, J.K. Nanomedicines for dental applications-scope and future perspective. Int. J. Pharm. Investig. 2015, 5, 121-123. [CrossRef] [PubMed]

6. Wang, H.; Leeuwenburgh, S.C.; Li, Y.; Jansen, J.A. The use of micro-and nanospheres as functional components for bone tissue regeneration. Tissue Eng. B Rev. 2011, 18, 24-39. [CrossRef] [PubMed]

7. Ortega-Oller, I.; Padial-Molina, M.; Galindo-Moreno, P.; O’Valle, F.; Jódar-Reyes, A.B.; Peula-García, J.M. Bone regeneration from PLGA micro-nanoparticles. BioMed Res. Int. 2015, 2015. [CrossRef] [PubMed]

8. Virlan, M.J.R.; Miricescu, D.; Totan, A.; Greabu, M.; Tanase, C.; Sabliov, C.M.; Caruntu, C.; Calenic, B. Current uses of poly(lactic-co-glycolic acid) in the dental field: A comprehensive review. J. Chem. 2015, 2015. [CrossRef]

9. Abdulkareem, E.H.; Memarzadeh, K.; Allaker, R.; Huang, J.; Pratten, J.; Spratt, D. Anti-biofilm activity of zinc oxide and hydroxyapatite nanoparticles as dental implant coating materials. J. Dent. 2015, 43, 1462-1469. [CrossRef] [PubMed]

10. Lappas, C.M. The immunomodulatory effects of titanium dioxide and silver nanoparticles. Food Chem. Toxicol. 2015, 85, 78-83. [CrossRef] [PubMed]

11. Shi, H.; Magaye, R.; Castranova, V.; Zhao, J. Titanium dioxide nanoparticles: A review of current toxicological data. Part Fibre Toxicol. 2013, 10, 15. [CrossRef] [PubMed]

12. Tautzenberger, A.; Kovtun, A.; Ignatius, A. Nanoparticles and their potential for application in bone. Int. J. Nanomed. 2012, 7, 4545-4557. [CrossRef] [PubMed]

13. Danhier, F.; Ansorena, E.; Silva, J.M.; Coco, R.; Le Breton, A.; Préat, V. PLGA-based nanoparticles: An overview of biomedical applications. J. Control. Release 2012, 161, 505-522. [CrossRef] 
14. Ige, O.O.; Umoru, L.E.; Aribo, S. Natural products: A minefield of biomaterials. ISRN Mater. Sci. $2012,2012$. [CrossRef]

15. Peng, H.; Yin, Z.; Liu, H.; Chen, X.; Feng, B.; Yuan, H.; Su, B.; Ouyang, H.; Zhang, Y. Electrospun biomimetic scaffold of hydroxyapatite/chitosan supports enhanced osteogenic differentiation of mMSCs. Nanotechnology 2012, 23, 485102. [CrossRef] [PubMed]

16. Laurencin, C.T.; Jiang, T.; Kumbar, S.G.; Nair, L.S. Biologically active chitosan systems for tissue engineering and regenerative medicine. Curr. Top. Med. Chem. 2008, 8, 354-364. [CrossRef]

17. Galler, K.; D'souza, R.; Hartgerink, J.; Schmalz, G. Scaffolds for dental pulp tissue engineering. Adv. Dent. Res. 2011, 23, 333-339. [CrossRef] [PubMed]

18. Bansal, V.; Sharma, P.K.; Sharma, N.; Pal, O.P.; Malviya, R. Applications of chitosan and chitosan derivatives in drug delivery. Adv. Biol. Res. 2011, 5, 28-37.

19. Bernkop-Schnürch, A.; Dünnhaupt, S. Chitosan-based drug delivery systems. Eur. J. Pharm. Biopharm. 2012, 81, 463-469. [CrossRef] [PubMed]

20. Laurencin, C.T.; Ashe, K.M.; Henry, N.; Kan, H.M.; Lo, K.W.-H. Delivery of small molecules for bone regenerative engineering: Preclinical studies and potential clinical applications. Drug Discov. Today 2014, 19, 794-800. [CrossRef] [PubMed]

21. Sonia, T.; Sharma, C.P. Chitosan and its derivatives for drug delivery perspective. In Chitosan for Biomaterials I; Springer: Heidelberg, Germany, 2011; pp. 23-53.

22. Chen, J.; Pan, P.; Zhang, Y.; Zhong, S.; Zhang, Q. Preparation of chitosan/nano hydroxyapatite organic-inorganic hybrid microspheres for bone repair. Colloids Surf. B Biointerfaces 2015, 134, 401-407. [CrossRef] [PubMed]

23. Meinel, L.; Betz, O.; Fajardo, R.; Hofmann, S.; Nazarian, A.; Cory, E.; Hilbe, M.; McCool, J.; Langer, R.; Vunjak-Novakovic, G. Silk based biomaterials to heal critical sized femur defects. Bone 2006, 39, 922-931. [CrossRef] [PubMed]

24. Vepari, C.; Kaplan, D.L. Silk as a biomaterial. Prog. Polym. Sci. 2007, 32, 991-1007. [CrossRef] [PubMed]

25. Wang, X.; Wenk, E.; Matsumoto, A.; Meinel, L.; Li, C.; Kaplan, D.L. Silk microspheres for encapsulation and controlled release. J. Control. Release 2007, 117, 360-370. [CrossRef] [PubMed]

26. Poth, N.; Seiffart, V.; Gross, G.; Menzel, H.; Dempwolf, W. Biodegradable chitosan nanoparticle coatings on titanium for the delivery of BMP-2. Biomolecules 2015, 5, 3-19. [CrossRef] [PubMed]

27. Eap, S.; Keller, L.; Schiavi, J.; Huck, O.; Jacomine, L.; Fioretti, F.; Gauthier, C.; Sebastian, V.; Schwinté, P.; Benkirane-Jessel, N. A living thick nanofibrous implant bifunctionalized with active growth factor and stem cells for bone regeneration. Int. J. Nanomed. 2015, 10, 1061-1075.

28. Eap, S.; Ferrand, A.; Schiavi, J.; Keller, L.; Kokten, T.; Fioretti, F.; Mainard, D.; Ladam, G.; Benkirane-Jessel, N. Collagen implants equipped with "fish scale"-like nanoreservoirs of growth factors for bone regeneration. Nanomedicine 2014, 9, 1253-1261. [CrossRef] [PubMed]

29. Shrestha, S.; Diogenes, A.; Kishen, A. Temporal-controlled dexamethasone releasing chitosan nanoparticle system enhances odontogenic differentiation of stem cells from apical papilla. J. Endod. 2015, 41, 1253-1258. [CrossRef] [PubMed]

30. Chronopoulou, L.; Nocca, G.; Castagnola, M.; Paludetti, G.; Ortaggi, G.; Sciubba, F.; Bevilacqua, M.; Lupi, A.; Gambarini, G.; Palocci, C. Chitosan based nanoparticles functionalized with peptidomimetic derivatives for oral drug delivery. New Biotechnol. 2016, 33, 23-31. [CrossRef] [PubMed]

31. Ferrand, A.; Eap, S.; Richert, L.; Lemoine, S.; Kalaskar, D.; Demoustier-Champagne, S.; Atmani, H.; Mély, Y.; Fioretti, F.; Schlatter, G. Osteogenetic properties of electrospun nanofibrous PCL scaffolds equipped with chitosan-based nanoreservoirs of growth factors. Macromol. Biosci. 2014, 14, 45-55. [CrossRef] [PubMed]

32. Cao, L.; Werkmeister, J.A.; Wang, J.; Glattauer, V.; McLean, K.M.; Liu, C. Bone regeneration using photocrosslinked hydrogel incorporating rhBMP-2 loaded 2- $\mathrm{N}$, 6-O-sulfated chitosan nanoparticles. Biomaterials 2014, 35, 2730-2742. [CrossRef] [PubMed]

33. Zhou, H.; Qian, J.; Wang, J.; Yao, W.; Liu, C.; Chen, J.; Cao, X. Enhanced bioactivity of bone morphogenetic protein-2 with low dose of 2-N, 6-O-sulfated chitosan in vitro and in vivo. Biomaterials 2009, 30, 1715-1724. [CrossRef]

34. Ho, M.-H.; Liao, M.-H.; Lin, Y.-L.; Lai, C.-H.; Lin, P.-I.; Chen, R.-M. Improving effects of chitosan nanofiber scaffolds on osteoblast proliferation and maturation. Int. J. Nanomed. 2014, 9, 4293-4304. 
35. Datta, P.; Ghosh, P.; Ghosh, K.; Maity, P.; Samanta, S.K.; Ghosh, S.K.; Mohapatra, P.K.D.; Chatterjee, J.; Dhara, S. In vitro ALP and osteocalcin gene expression analysis and in vivo biocompatibility of $N$-methylene phosphonic chitosan nanofibers for bone regeneration. J. Biomed. Nanotechnol. 2013, 9, 870-879. [CrossRef] [PubMed]

36. Romero, R.; Chubb, L.; Travers, J.K.; Gonzales, T.R.; Ehrhart, N.P.; Kipper, M.J. Coating cortical bone allografts with periosteum-mimetic scaffolds made of chitosan, trimethyl chitosan, and heparin. Carbohydr. Polym. 2015, 122, 144-151. [CrossRef] [PubMed]

37. Shrestha, S.; Diogenes, A.; Kishen, A. Temporal-controlled release of bovine serum albumin from chitosan nanoparticles: Effect on the regulation of alkaline phosphatase activity in stem cells from apical papilla. J. Endod. 2014, 40, 1349-1354. [CrossRef] [PubMed]

38. Zhang, X.; Li, Y.; Sun, X.; Kishen, A.; Deng, X.; Yang, X.; Wang, H.; Cong, C.; Wang, Y.; Wu, M. Biomimetic remineralization of demineralized enamel with nano-complexes of phosphorylated chitosan and amorphous calcium phosphate. J. Mater. Sci. Mater. Med. 2014, 25, 2619-2628. [CrossRef] [PubMed]

39. DenBesten, P.; Li, W. Chronic fluoride toxicity: Dental fluorosis. Monogr Oral Sci. 2011, 22, 81-96. [PubMed]

40. Shrestha, A.; Zhilong, S.; Gee, N.K.; Kishen, A. Nanoparticulates for antibiofilm treatment and effect of aging on its antibacterial activity. J. Endod. 2010, 36, 1030-1035. [CrossRef] [PubMed]

41. Shrestha, A.; Kishen, A. The effect of tissue inhibitors on the antibacterial activity of chitosan nanoparticles and photodynamic therapy. J. Endod. 2012, 38, 1275-1278. [CrossRef] [PubMed]

42. Rabea, E.I.; Badawy, M.E.-T.; Stevens, C.V.; Smagghe, G.; Steurbaut, W. Chitosan as antimicrobial agent: Applications and mode of action. Biomacromolecules 2003, 4, 1457-1465. [CrossRef] [PubMed]

43. Upadya, M.; Shrestha, A.; Kishen, A. Role of efflux pump inhibitors on the antibiofilm efficacy of calcium hydroxide, chitosan nanoparticles, and light-activated disinfection. J. Endod. 2011, 37, 1422-1426. [CrossRef] [PubMed]

44. Kishen, A.; Shi, Z.; Shrestha, A.; Neoh, K.G. An investigation on the antibacterial and antibiofilm efficacy of cationic nanoparticulates for root canal disinfection. J. Endod. 2008, 34, 1515-1520. [CrossRef] [PubMed]

45. Del Carpio-Perochena, A.; Kishen, A.; Shrestha, A.; Bramante, C.M. Antibacterial properties associated with chitosan nanoparticle treatment on root dentin and 2 types of endodontic sealers. J. Endod. 2015, 41, 1353-1358. [CrossRef] [PubMed]

46. Del Carpio-Perochena, A.; Bramante, C.M.; Duarte, M.A.H.; de Moura, M.R.; Aouada, F.A.; Kishen, A. Chelating and antibacterial properties of chitosan nanoparticles on dentin. Restor. Dent. Endod. 2015, 40, 195-201. [CrossRef] [PubMed]

47. DaSilva, L.; Finer, Y.; Friedman, S.; Basrani, B.; Kishen, A. Biofilm formation within the interface of bovine root dentin treated with conjugated chitosan and sealer containing chitosan nanoparticles. J. Endod. 2013, 39, 249-253. [CrossRef] [PubMed]

48. Hamilton, M.F.; Otte, A.D.; Gregory, R.L.; Pinal, R.; Ferreira-Zandoná, A.; Bottino, M.C. Physicomechanical and antibacterial properties of experimental resin-based dental sealants modified with nylon- 6 and chitosan nanofibers. J. Biomed. Mater. Res. B Appl. Biomater. 2014, 103, 1560-1568. [CrossRef] [PubMed]

49. Liu, H.; Chen, B.; Mao, Z.; Gao, C. Chitosan nanoparticles for loading of toothpaste actives and adhesion on tooth analogs. J. Appl. Polym. Sci. 2007, 106, 4248-4256. [CrossRef]

50. De Paz, L.E.C.; Resin, A.; Howard, K.A.; Sutherland, D.S.; Wejse, P.L. Antimicrobial effect of chitosan nanoparticles on streptococcus mutans biofilms. Appl. Environ. Microbiol. 2011, 77, 3892-3895. [CrossRef] [PubMed]

51. Loesche, W.J. Role of streptococcus mutans in human dental decay. Microbiol. Rev. 1986, 50, $353-380$. [PubMed]

52. Moye, Z.D.; Zeng, L.; Burne, R.A. Fueling the caries process: Carbohydrate metabolism and gene regulation by streptococcus mutans. J. Oral Microbiol. 2014, 6. [CrossRef] [PubMed]

53. Razavi, S.; Zarkesh-Esfahani, H.; Morshed, M.; Vaezifar, S.; Karbasi, S.; Golozar, M.A. Nanobiocomposite of poly(lactide-co-glycolide)/chitosan electrospun scaffold can promote proliferation and transdifferentiation of schwann-like cells from human adipose-derived stem cells. J. Biomed. Mater. Res. A 2015, 103, 2628-2634. [CrossRef] [PubMed]

54. Lin, H.-Y.; Chen, S.-H.; Chang, S.-H.; Huang, S.-T. Tri-layered chitosan scaffold as a potential skin substitute. J. Biomater. Sci. Polym. Ed. 2015, 26, 855-867. [CrossRef] [PubMed] 
55. Kossovich, L.; Salkovskiy, Y.; Kirillova, I. Electrospun chitosan nanofiber materials as burn dressing. In Proceedings of the 6th World Congress of Biomechanics (WCB 2010), Singapore, 1-6 August 2010; Springer: Heidelberg, Germany; pp. 1212-1214.

56. Noh, H.K.; Lee, S.W.; Kim, J.-M.; Oh, J.-E.; Kim, K.-H.; Chung, C.-P.; Choi, S.-C.; Park, W.H.; Min, B.-M. Electrospinning of chitin nanofibers: Degradation behavior and cellular response to normal human keratinocytes and fibroblasts. Biomaterials 2006, 27, 3934-3944. [CrossRef] [PubMed]

57. Mansur, A.A.; de Carvalho, S.M.; Mansur, H.S. Bioengineered quantum dot/chitosan-tripeptide nanoconjugates for targeting the receptors of cancer cells. Int. J. Biol. Macromol. 2015, 82, 780-789. [CrossRef] [PubMed]

58. Jayakumar, R.; Menon, D.; Manzoor, K.; Nair, S.; Tamura, H. Biomedical applications of chitin and chitosan based nanomaterials-A short review. Carbohydr. Polym. 2010, 82, 227-232. [CrossRef]

59. Ramasamy, T.; Tran, T.H.; Cho, H.J.; Kim, J.H.; Kim, Y.I.; Jeon, J.Y.; Choi, H.-G.; Yong, C.S.; Kim, J.O. Chitosan-based polyelectrolyte complexes as potential nanoparticulate carriers: Physicochemical and biological characterization. Pharm. Res. 2014, 31, 1302-1314. [CrossRef] [PubMed]

60. David, K.I.; Jaidev, L.R.; Sethuraman, S.; Krishnan, U.M. Dual drug loaded chitosan nanoparticles-sugarcoated arsenal against pancreatic cancer. Colloids Surf. B Biointerfaces 2015, 135, 689-698. [CrossRef] [PubMed]

61. Nogueira, D.R.; Tavano, L.; Mitjans, M.; Pérez, L.; Infante, M.R.; Vinardell, M.P. In vitro antitumor activity of methotrexate via pH-sensitive chitosan nanoparticles. Biomaterials 2013, 34, 2758-2772. [CrossRef] [PubMed]

62. Machiels, J.-P.H.; Haddad, R.I.; Fayette, J.; Licitra, L.F.; Tahara, M.; Vermorken, J.B.; Clement, P.M.; Gauler, T.; Cupissol, D.; Grau, J.J. Afatinib versus methotrexate as second-line treatment in patients with recurrent or metastatic squamous-cell carcinoma of the head and neck progressing on or after platinum-based therapy (lux-head \& neck 1): An open-label, randomised phase 3 trial. Lancet Oncol. 2015, 16, 583-594. [PubMed]

63. Rao, W.; Wang, H.; Han, J.; Zhao, S.; Dumbleton, J.; Agarwal, P.; Zhang, W.; Zhao, G.; Yu, J.; Zynger, D.L. Chitosan-decorated doxorubicin-encapsulated nanoparticle targets and eliminates tumor reinitiating cancer stem-like cells. ACS Nano 2015, 9, 5725-5740. [CrossRef] [PubMed]

64. Alshaer, W.; Hillaireau, H.; Vergnaud, J.; Ismail, S.; Fattal, E. Functionalizing liposomes with anti-CD44 aptamer for selective targeting of cancer cells. Bioconj. Chem. 2015, 26, 1307-1313. [CrossRef] [PubMed]

65. Biddle, A.; Liang, X.; Gammon, L.; Fazil, B.; Harper, L.J.; Emich, H.; Costea, D.E.; Mackenzie, I.C. Cancer stem cells in squamous cell carcinoma switch between two distinct phenotypes that are preferentially migratory or proliferative. Cancer Res. 2011, 71, 5317-5326. [CrossRef] [PubMed]

66. Harper, L.J.; Costea, D.E.; Gammon, L.; Fazil, B.; Biddle, A.; Mackenzie, I.C. Normal and malignant epithelial cells with stem-like properties have an extended G2 cell cycle phase that is associated with apoptotic resistance. BMC Cancer 2010, 10, 166. [CrossRef] [PubMed]

67. Jeevitha, D.; Amarnath, K. Chitosan/pla nanoparticles as a novel carrier for the delivery of anthraquinone: Synthesis, characterization and in vitro cytotoxicity evaluation. Colloids Surf. B Biointerfaces 2013, 101, 126-134. [CrossRef] [PubMed]

68. Bhattarai, G.; Lee, Y.; Lee, M.; Yi, H. Gene delivery of c-myb increases bone formation surrounding oral implants. J. Dent. Res. 2013, 92, 840-845. [CrossRef] [PubMed]

69. Bhattarai, G.; Lee, Y.H.; Lee, N.H.; Park, I.S.; Lee, M.H.; Yi, H.K. PPAR $\gamma$ delivered by Ch-GNPs onto titanium surfaces inhibits implant-induced inflammation and induces bone mineralization of MC-3T3E1 osteoblast-like cells. Clin. Oral Implant. Res. 2013, 24, 1101-1109. [CrossRef] [PubMed]

70. Bhattarai, G.; Lee, Y.H.; Yi, H.K. Peroxisome proliferator activated receptor gamma loaded dental implant improves osteogenesis of rat mandible. J. Biomed. Mater. Res. B Appl. Biomater. 2015, 103, 587-595. [CrossRef] [PubMed]

71. Hassumi, M.Y.; Silva-Filho, V.J.; Campos-Júnior, J.C.; Vieira, S.M.; Cunha, F.Q.; Alves, P.M.; Alves, J.B.; Kawai, T.; Gonçalves, R.B.; Napimoga, M.H. Ppar- $\gamma$ agonist rosiglitazone prevents inflammatory periodontal bone loss by inhibiting osteoclastogenesis. Int. Immunopharmacol. 2009, 9, 1150-1158. [CrossRef] [PubMed]

72. Di Paola, R.; Mazzon, E.; Maiere, D.; Zito, D.; Britti, D.; De Majo, M.; Genovese, T.; Cuzzocrea, S. Rosiglitazone reduces the evolution of experimental periodontitis in the rat. J. Dent. Res. 2006, 85, 156-161. [CrossRef] [PubMed]

73. Lee, Y.-H.; Kang, Y.-M.; Heo, M.-J.; Kim, G.-E.; Bhattarai, G.; Lee, N.-H.; Yu, M.-K.; Yi, H.-K. The survival role of peroxisome proliferator-activated receptor gamma induces odontoblast differentiation against oxidative stress in human dental pulp cells. J. Endod. 2013, 39, 236-241. [CrossRef] [PubMed] 
74. Yu, M.-K.; Lee, J.-C.; Kim, J.-H.; Lee, Y.-H.; Jeon, J.-G.; Jhee, E.-C.; Yi, H.-K. Anti-inflammatory effect of peroxisome proliferator activated receptor gamma on human dental pulp cells. J. Endod. 2009, 35, 524-528. [CrossRef] [PubMed]

75. Kim, T.-G.; Lee, Y.-H.; Lee, N.-H.; Bhattarai, G.; Lee, I.-K.; Yun, B.-S.; Yi, H.-K. The antioxidant property of pachymic acid improves bone disturbance against AH plus-induced inflammation in MC-3T3E1 cells. J. Endod. 2013, 39, 461-466. [CrossRef] [PubMed]

76. Jing, X.; Mi, H.-Y.; Peng, J.; Peng, X.-F.; Turng, L.-S. Electrospun aligned poly(propylene carbonate) microfibers with chitosan nanofibers as tissue engineering scaffolds. Carbohydr. Polym. 2015, 117, 941-949. [CrossRef] [PubMed]

77. Cheng, Y.; Ramos, D.; Lee, P.; Liang, D.; Yu, X.; Kumbar, S.G. Collagen functionalized bioactive nanofiber matrices for osteogenic differentiation of mesenchymal stem cells: Bone tissue engineering. J. Biomed. Nanotechnol. 2014, 10, 287-298. [CrossRef] [PubMed]

78. Jing, X.; Mi, H.-Y.; Wang, X.-C.; Peng, X.-F.; Turng, L.-S. Shish-kebab-structured poly( $\varepsilon$-caprolactone) nanofibers hierarchically decorated with chitosan-poly( $\varepsilon$-caprolactone) copolymers for bone tissue engineering. ACS Appl. Mater. Interfaces 2015, 7, 6955-6965. [CrossRef] [PubMed]

79. Hou, Y.; Hu, J.; Park, H.; Lee, M. Chitosan-based nanoparticles as a sustained protein release carrier for tissue engineering applications. J. Biomed. Mater. Res. A 2012, 100, 939-947. [CrossRef] [PubMed]

80. Zhang, Y.; Venugopal, J.R.; El-Turki, A.; Ramakrishna, S.; Su, B.; Lim, C.T. Electrospun biomimetic nanocomposite nanofibers of hydroxyapatite/chitosan for bone tissue engineering. Biomaterials 2008, 29, 4314-4322. [CrossRef] [PubMed]

81. Liu, H.; Peng, H.; Wu, Y.; Zhang, C.; Cai, Y.; Xu, G.; Li, Q.; Chen, X.; Ji, J.; Zhang, Y. The promotion of bone regeneration by nanofibrous hydroxyapatite/chitosan scaffolds by effects on integrin-bmp/smad signaling pathway in bmscs. Biomaterials 2013, 34, 4404-4417. [CrossRef] [PubMed]

82. Kumar, P.S.; Srinivasan, S.; Lakshmanan, V.-K.; Tamura, H.; Nair, S.; Jayakumar, R. Synthesis, characterization and cytocompatibility studies of $\alpha$-chitin hydrogel/nano hydroxyapatite composite scaffolds. Int. J. Biol. Macromol. 2011, 49, 20-31. [CrossRef] [PubMed]

83. Yang, D.; Jin, Y.; Zhou, Y.; Ma, G.; Chen, X.; Lu, F.; Nie, J. In situ mineralization of hydroxyapatite on electrospun chitosan-based nanofibrous scaffolds. Macromol. Biosci. 2008, 8, 239-246. [CrossRef] [PubMed]

84. Zhang, Y.; Reddy, V.J.; Wong, S.Y.; Li, X.; Su, B.; Ramakrishna, S.; Lim, C.T. Enhanced biomineralization in osteoblasts on a novel electrospun biocomposite nanofibrous substrate of hydroxyapatite/collagen/chitosan. Tissue Eng. A 2010, 16, 1949-1960. [CrossRef] [PubMed]

85. Zhang, S.; Prabhakaran, M.P.; Qin, X.; Ramakrishna, S. Biocomposite scaffolds for bone regeneration: Role of chitosan and hydroxyapatite within poly-3-hydroxybutyrate-co-3-hydroxyvalerate on mechanical properties and in vitro evaluation. J. Mech. Behav. Biomed. Mater. 2015, 51, 88-98. [CrossRef] [PubMed]

86. Zhong, Z.; Qin, J.; Ma, J. Cellulose acetate/hydroxyapatite/chitosan coatings for improved corrosion resistance and bioactivity. Mater. Sci. Eng. C 2015, 49, 251-255. [CrossRef] [PubMed]

87. Lin, C.-C.; Fu, S.-J.; Lin, Y.-C.; Yang, I.-K.; Gu, Y. Chitosan-coated electrospun PLA fibers for rapid mineralization of calcium phosphate. Int. J. Biol. Macromol. 2014, 68, 39-47. [CrossRef] [PubMed]

88. Subramanian, A.; Vu, D.; Larsen, G.F.; Lin, H.-Y. Preparation and evaluation of the electrospun chitosan/peo fibers for potential applications in cartilage tissue engineering. J. Biomater. Sci. Polym. Ed. 2005, 16, 861-873. [CrossRef] [PubMed]

89. Tonglairoum, P.; Ngawhirunpat, T.; Rojanarata, T.; Panomsuk, S.; Kaomongkolgit, R.; Opanasopit, P. Fabrication of mucoadhesive chitosan coated polyvinylpyrrolidone/cyclodextrin/clotrimazole sandwich patches for oral candidiasis. Carbohydr. Polym. 2015, 132, 173-179. [CrossRef] [PubMed]

90. Jiang, W.; Li, L.; Zhang, D.; Huang, S.; Jing, Z.; Wu, Y.; Zhao, Z.; Zhao, L.; Zhou, S. Incorporation of aligned pcl-peg nanofibers into porous chitosan scaffolds improved the orientation of collagen fibers in regenerated periodontium. Acta Biomater. 2015, 25, 240-252. [CrossRef] [PubMed]

91. Bertoncelj, V.; Pelipenko, J.; Kristl, J.; Jeras, M.; Cukjati, M.; Kocbek, P. Development and bioevaluation of nanofibers with blood-derived growth factors for dermal wound healing. Eur. J. Pharm. Biopharm. 2014, 88, 64-74. [CrossRef] [PubMed]

92. Lou, T.; Leung, M.; Wang, X.; Chang, J.Y.F.; Tsao, C.T.; Sham, J.G.C.; Edmondson, D.; Zhang, M. Bi-layer scaffold of chitosan/PCL-nanofibrous mat and PLLA-microporous disc for skin tissue engineering. J. Biomed. Nanotechnol. 2014, 10, 1105-1113. [CrossRef] [PubMed] 
93. Sarhan, W.A.; Azzazy, H.M. High concentration honey chitosan electrospun nanofibers: Biocompatibility and antibacterial effects. Carbohydr. Polym. 2015, 122, 135-143. [CrossRef] [PubMed]

94. Chen, J.-P.; Chang, G.-Y.; Chen, J.-K. Electrospun collagen/chitosan nanofibrous membrane as wound dressing. Colloids Surf. A Physicochem. Eng. Asp. 2008, 313, 183-188. [CrossRef]

95. Kumar, P.S.; Raj, N.M.; Praveen, G.; Chennazhi, K.P.; Nair, S.V.; Jayakumar, R. In vitro and in vivo evaluation of microporous chitosan hydrogel/nanofibrin composite bandage for skin tissue regeneration. Tissue Eng. A 2012, 19, 380-392. [CrossRef] [PubMed]

96. Zhao, R.; Li, X.; Sun, B.; Zhang, Y.; Zhang, D.; Tang, Z.; Chen, X.; Wang, C. Electrospun chitosan/sericin composite nanofibers with antibacterial property as potential wound dressings. Int. J. Biol. Macromol. 2014, 68, 92-97. [CrossRef] [PubMed]

97. Choi, J.S.; Han, S.H.; Hyun, C.; Yoo, H.S. Buccal adhesive nanofibers containing human growth hormone for oral mucositis. J. Biomed. Mater. Res. B Appl. Biomater. 2015. [CrossRef] [PubMed]

98. Antunes, B.; Moreira, A.; Gaspar, V.; Correia, I. Chitosan/arginine-chitosan polymer blends for assembly of nanofibrous membranes for wound regeneration. Carbohydr. Polym. 2015, 130, 104-112. [CrossRef] [PubMed]

99. Tan, L.; Hu, J.; Huang, H.; Han, J.; Hu, H. Study of multi-functional electrospun composite nanofibrous mats for smart wound healing. Int. J. Biol. Macromol. 2015, 79, 469-476. [CrossRef] [PubMed]

100. Xu, F.; Weng, B.; Gilkerson, R.; Materon, L.A.; Lozano, K. Development of tannic acid/chitosan/pullulan composite nanofibers from aqueous solution for potential applications as wound dressing. Carbohydr. Polym. 2015, 115, 16-24. [CrossRef] [PubMed]

101. Shrestha, A.; Hamblin, M.R.; Kishen, A. Photoactivated rose bengal functionalized chitosan nanoparticles produce antibacterial/biofilm activity and stabilize dentin-collagen. Nanomed. Nanotechnol. Biol. Med. 2014, 10, 491-501. [CrossRef] [PubMed]

102. Tonglairoum, P.; Ngawhirunpat, T.; Rojanarata, T.; Kaomongkolgit, R.; Opanasopit, P. Fabrication of a novel scaffold of clotrimazole-microemulsion-containing nanofibers using an electrospinning process for oral candidiasis applications. Colloids Surf. B Biointerfaces 2015, 126, 18-25. [CrossRef] [PubMed]

103. Wang, X.; Cheng, F.; Gao, J.; Wang, L. Antibacterial wound dressing from chitosan/polyethylene oxide nanofibers mats embedded with silver nanoparticles. J. Biomater. Appl. 2015, 29, 1086-1095. [CrossRef] [PubMed]

104. Croisier, F.; Sibret, P.; Dupont-Gillain, C.C.; Genet, M.J.; Detrembleur, C.; Jérôme, C. Chitosan-coated electrospun nanofibers with antibacterial activity. J. Mater. Chem. B 2015, 3, 3508-3517. [CrossRef]

105. Gholipour-Kanani, A.; Bahrami, S.H.; Joghataie, M.T.; Samadikuchaksaraei, A.; Ahmadi-Taftie, H.; Rabbani, S.; Kororian, A.; Erfani, E. Tissue engineered poly(caprolactone)-chitosan-poly(vinyl alcohol) nanofibrous scaffolds for burn and cutting wound healing. IET Nanobiotechnol. 2014, 8, 123-131. [CrossRef] [PubMed]

106. Koosha, M.; Mirzadeh, H. Electrospinning, mechanical properties, and cell behavior study of chitosan/PVA nanofibers. J. Biomed. Mater. Res. A 2015, 103, 3081-30963. [CrossRef] [PubMed]

107. Zhou, Y.; Yang, D.; Chen, X.; Xu, Q.; Lu, F.; Nie, J. Electrospun water-soluble carboxyethyl chitosan/poly(vinyl alcohol) nanofibrous membrane as potential wound dressing for skin regeneration. Biomacromolecules 2007, 9, 349-354. [CrossRef] [PubMed]

108. Chen, Z.; Cao, S.; Wang, H.; Li, Y.; Kishen, A.; Deng, X.; Yang, X.; Wang, Y.; Cong, C.; Wang, H. Biomimetic remineralization of demineralized dentine using scaffold of CMC/ACP nanocomplexes in an in vitro tooth model of deep caries. PLOS ONE 2015, 10, e0116553. [CrossRef] [PubMed]

109. Targino, A.G.R.; Flores, M.A.P.; dos Santos Junior, V.E.; Bezerra, F.D.G.B.; de Freire, L.H.; Galembeck, A.; Rosenblatt, A. An innovative approach to treating dental decay in children. A new anti-caries agent. J. Mater. Sci. Mater. Med. 2014, 25, 2041-2047. [CrossRef] [PubMed]

110. Liu, Y.; Liu, Y.; Liao, N.; Cui, F.; Park, M.; Kim, H.-Y. Fabrication and durable antibacterial properties of electrospun chitosan nanofibers with silver nanoparticles. Int. J. Biol. Macromol. 2015, 79, 638-643. [CrossRef] [PubMed]

111. Rhim, J.-W.; Hong, S.-I.; Park, H.-M.; Ng, P.K. Preparation and characterization of chitosan-based nanocomposite films with antimicrobial activity. J. Agric. Food Chem. 2006, 54, 5814-5822. [CrossRef] [PubMed]

112. Sanpui, P.; Murugadoss, A.; Prasad, P.D.; Ghosh, S.S.; Chattopadhyay, A. The antibacterial properties of a novel chitosan-Ag-nanoparticle composite. Int. J. Food Microbiol. 2008, 124, 142-146. [CrossRef] [PubMed] 
113. Cao, X.; Cheng, C.; Ma, Y.; Zhao, C. Preparation of silver nanoparticles with antimicrobial activities and the researches of their biocompatibilities. J. Mater. Sci. Mater. Med. 2010, 21, 2861-2868. [CrossRef] [PubMed]

114. Shrestha, A.; Kishen, A. Antibiofilm efficacy of photosensitizer-functionalized bioactive nanoparticles on multispecies biofilm. J. Endod. 2014, 40, 1604-1610. [CrossRef] [PubMed]

115. Shrestha, A.; Kishen, A. Polycationic chitosan-conjugated photosensitizer for antibacterial photodynamic therapy. Photochem. Photobiol. 2012, 88, 577-583. [CrossRef] [PubMed]

116. Saatchi, M.; Shokraneh, A.; Navaei, H.; Maracy, M.R.; Shojaei, H. Antibacterial effect of calcium hydroxide combined with chlorhexidine on Enterococcus faecalis: A systematic review and meta-analysis. J. Appl. Oral Sci. 2014, 22, 356-365. [CrossRef] [PubMed]

117. Greabu, M.; Virlan, M.J.R.; Calenic, B.; Zaharia, C. Silk fibroin and potential uses in regenerative dentistry-A systematic review. Stomatol. Educ. J. 2015, 1, 108-115.

118. Wenk, E.; Merkle, H.P.; Meinel, L. Silk fibroin as a vehicle for drug delivery applications. J. Control. Release 2011, 150, 128-141. [CrossRef] [PubMed]

119. Li, C.; Vepari, C.; Jin, H.-J.; Kim, H.J.; Kaplan, D.L. Electrospun silk-BMP-2 scaffolds for bone tissue engineering. Biomaterials 2006, 27, 3115-3124. [CrossRef] [PubMed]

120. Kim, K.-H.; Jeong, L.; Park, H.-N.; Shin, S.-Y.; Park, W.-H.; Lee, S.-C.; Kim, T.-I.; Park, Y.-J.; Seol, Y.-J.; Lee, Y.-M. Biological efficacy of silk fibroin nanofiber membranes for guided bone regeneration. J. Biotechnol. 2005, 120, 327-339. [CrossRef] [PubMed]

121. Liu, L.; Zhang, X.; Liu, X.; Liu, J.; Lu, G.; Kaplan, D.L.; Zhu, H.; Lu, Q. Biomineralization of stable and monodisperse vaterite microspheres using silk nanoparticles. ACS Appl. Mater. Interfaces 2015, 7, 1735-1745. [CrossRef] [PubMed]

122. Lai, G.-J.; Shalumon, K.; Chen, S.-H.; Chen, J.-P. Composite chitosan/silk fibroin nanofibers for modulation of osteogenic differentiation and proliferation of human mesenchymal stem cells. Carbohydr. Polym. 2014, 111, 288-297. [CrossRef] [PubMed]

123. Lai, G.-J.; Shalumon, K.; Chen, J.-P. Response of human mesenchymal stem cells to intrafibrillar nanohydroxyapatite content and extrafibrillar nanohydroxyapatite in biomimetic chitosan/silk fibroin/nanohydroxyapatite nanofibrous membrane scaffolds. Int. J. Nanomed. 2015, 10, 567-584.

124. Shalumon, K.; Lai, G.-J.; Chen, C.-H.; Chen, J.-P. Modulation of bone-specific tissue regeneration by incorporating bone morphogenetic protein and controlling the shell thickness of silk fibroin/chitosan/nanohydroxyapatite core-shell nanofibrous membranes. ACS Appl. Mater. Interfaces 2015, 7, 21170-21181. [CrossRef] [PubMed]

125. Yoo, C.R.; Yeo, I.-S.; Park, K.E.; Park, J.H.; Lee, S.J.; Park, W.H.; Min, B.-M. Effect of chitin/silk fibroin nanofibrous bicomponent structures on interaction with human epidermal keratinocytes. Int. J. Biol. Macromol. 2008, 42, 324-334. [CrossRef] [PubMed]

126. Park, K.E.; Jung, S.Y.; Lee, S.J.; Min, B.-M.; Park, W.H. Biomimetic nanofibrous scaffolds: Preparation and characterization of chitin/silk fibroin blend nanofibers. Int. J. Biol. Macromol. 2006, 38, 165-173. [CrossRef] [PubMed]

127. Cai, Z.-X.; Mo, X.-M.; Zhang, K.-H.; Fan, L.-P.; Yin, A.-L.; He, C.-L.; Wang, H.-S. Fabrication of chitosan/silk fibroin composite nanofibers for wound-dressing applications. Int. J. Mol. Sci. 2010, 11, 3529-3539. [CrossRef] [PubMed]

128. Dunne, L.W.; Iyyanki, T.; Hubenak, J.; Mathur, A.B. Characterization of dielectrophoresis-aligned nanofibrous silk fibroin-chitosan scaffold and its interactions with endothelial cells for tissue engineering applications. Acta Biomater. 2014, 10, 3630-3640. [CrossRef] [PubMed]

129. Numata, K.; Mieszawska-Czajkowska, A.J.; Kvenvold, L.A.; Kaplan, D.L. Silk-based nanocomplexes with tumor-homing peptides for tumor-specific gene delivery. Macromol. Biosci. 2012, 12, 75-82. [CrossRef] [PubMed]

130. Qu, J.; Liu, Y.; Yu, Y.; Li, J.; Luo, J.; Li, M. Silk fibroin nanoparticles prepared by electrospray as controlled release carriers of cisplatin. Mater. Sci. Eng. C 2014, 44, 166-174. [CrossRef] [PubMed]

131. Marin, E.; Briceño, M.I.; Caballero-George, C. Critical evaluation of biodegradable polymers used in nanodrugs. Int. J. Nanomed. 2013, 8, 3071-3090.

132. Lü, J.-M.; Wang, X.; Marin-Muller, C.; Wang, H.; Lin, P.H.; Yao, Q.; Chen, C. Current advances in research and clinical applications of PLGA-based nanotechnology. Expert Rev. Mol. Diagn. 2009, 9, 325-341. [CrossRef] [PubMed] 
133. Liu, H.; Slamovich, E.B.; Webster, T.J. Less harmful acidic degradation of poly(lactic-co-glycolic acid) bone tissue engineering scaffolds through titania nanoparticle addition. Int. J. Nanomed. 2006, 1, 541-545. [CrossRef]

134. Kashi, T.S.J.; Eskandarion, S.; Esfandyari-Manesh, M.; Marashi, S.M.A.; Samadi, N.; Fatemi, S.M.; Atyabi, F.; Eshraghi, S.; Dinarvand, R. Improved drug loading and antibacterial activity of minocycline-loaded PLGA nanoparticles prepared by solid/oil/water ion pairing method. Int. J. Nanomed. 2012, 7, 221-234.

135. Pagonis, T.C.; Chen, J.; Fontana, C.R.; Devalapally, H.; Ruggiero, K.; Song, X.; Foschi, F.; Dunham, J.; Skobe, Z.; Yamazaki, H. Nanoparticle-based endodontic antimicrobial photodynamic therapy. J. Endod. 2010, 36, 322-328. [CrossRef] [PubMed]

136. Chereddy, K.K.; Coco, R.; Memvanga, P.B.; Ucakar, B.; des Rieux, A.; Vandermeulen, G.; Préat, V. Combined effect of PLGA and curcumin on wound healing activity. J. Control. Release 2013, 171, 208-215. [CrossRef] [PubMed]

137. Chereddy, K.K.; Her, C.-H.; Comune, M.; Moia, C.; Lopes, A.; Porporato, P.E.; Vanacker, J.; Lam, M.C.; Steinstraesser, L.; Sonveaux, P. PLGA nanoparticles loaded with host defense peptide LL37 promote wound healing. J. Control. Release 2014, 194, 138-147. [CrossRef] [PubMed]

138. Chereddy, K.K.; Lopes, A.; Koussoroplis, S.; Payen, V.; Moia, C.; Zhu, H.; Sonveaux, P.; Carmeliet, P.; des Rieux, A.; Vandermeulen, G. Combined effects of PLGA and vascular endothelial growth factor promote the healing of non-diabetic and diabetic wounds. Nanomed. Nanotechnol. Biol. Med. 2015, 11, 1975-1984. [CrossRef] [PubMed]

139. Gentile, P.; Nandagiri, V.K.; Pabari, R.; Daly, J.; Tonda-Turo, C.; Ciardelli, G.; Ramtoola, Z. Influence of parathyroid hormone-loaded PLGA nanoparticles in porous scaffolds for bone regeneration. Int. J. Mol. Sci. 2015, 16, 20492-20510. [CrossRef] [PubMed]

140. Park, J.S.; Yang, H.N.; Woo, D.G.; Jeon, S.Y.; Do, H.-J.; Lim, H.-Y.; Kim, J.-H.; Park, K.-H. Chondrogenesis of human mesenchymal stem cells mediated by the combination of sox trio SOX5, 6, and 9 genes complexed with PEI-modified PLGA nanoparticles. Biomaterials 2011, 32, 3679-3688. [CrossRef] [PubMed]

141. Kim, J.-H.; Park, J.S.; Yang, H.N.; Woo, D.G.; Jeon, S.Y.; Do, H.-J.; Lim, H.-Y.; Kim, J.M.; Park, K.-H. The use of biodegradable PLGA nanoparticles to mediate SOX9 gene delivery in human mesenchymal stem cells (hMSCs) and induce chondrogenesis. Biomaterials 2011, 32, 268-278. [CrossRef] [PubMed]

142. Jeon, S.Y.; Park, J.S.; Yang, H.N.; Woo, D.G.; Park, K.-H. Aggrecan-and comp-loaded poly-(lactic-co-glycolic acid) nanoparticles stimulate chondrogenic differentiation of human mesenchymal stem cells. Stem Cells Dev. 2013, 23, 305-317. [CrossRef] [PubMed]

143. Jeon, S.Y.; Park, J.S.; Yang, H.N.; Lim, H.J.; Yi, S.W.; Park, H.; Park, K.-H. Co-delivery of Cbfa-1-targeting siRNA and SOX9 protein using PLGA nanoparticles to induce chondrogenesis of human mesenchymal stem cells. Biomaterials 2014, 35, 8236-8248. [CrossRef] [PubMed]

144. Yang, H.N.; Park, J.S.; Woo, D.G.; Jeon, S.Y.; Do, H.-J.; Lim, H.-Y.; Kim, S.W.; Kim, J.-H.; Park, K.-H. Chondrogenesis of mesenchymal stem cells and dedifferentiated chondrocytes by transfection with SOX trio genes. Biomaterials 2011, 32, 7695-7704. [CrossRef] [PubMed]

145. Wei, G.; Jin, Q.; Giannobile, W.V.; Ma, P.X. The enhancement of osteogenesis by nano-fibrous scaffolds incorporating rhBMP-7 nanospheres. Biomaterials 2007, 28, 2087-2096. [CrossRef] [PubMed]

146. Pillai, R.R.; Somayaji, S.N.; Rabinovich, M.; Hudson, M.C.; Gonsalves, K.E. Nafcillin-loaded PLGA nanoparticles for treatment of osteomyelitis. Biomedical Mater. 2008, 3, 034114. [CrossRef] [PubMed]

147. Wang, H.; Liu, J.; Tao, S.; Chai, G.; Wang, J.; Hu, F.-Q.; Yuan, H. Tetracycline-grafted PLGA nanoparticles as bone-targeting drug delivery system. Int. J. Nanomed. 2015, 10, 5671-5685.

148. Garrett, I.; Gutierrez, G.; Rossini, G.; Nyman, J.; McCluskey, B.; Flores, A.; Mundy, G. Locally delivered lovastatin nanoparticles enhance fracture healing in rats. J. Orthop. Res. 2007, 25, 1351-1357. [CrossRef] [PubMed]

149. Chronopoulou, L.; Amalfitano, A.; Palocci, C.; Nocca, G.; Callà, C.; Arcovito, A. Dexamethasone-loaded biopolymeric nanoparticles promote gingival fibroblasts differentiation. Biotechnol. Prog. 2015, 31, 1381-1387. [CrossRef] [PubMed]

150. Souza, A.; Nascimento, A.; de Vasconcelos, N.; Jerônimo, M.; Siqueira, I.; R-Santos, L.; Cintra, D.; Fuscaldi, L.; Júnior, O.P.; Titze-de-Almeida, R. Activity and in vivo tracking of amphotericin B loaded PLGA nanoparticles. Eur. J. Med. Chem. 2015, 95, 267-276. [CrossRef] [PubMed] 
151. Radcliffe, C.; Potouridou, L.; Qureshi, R.; Habahbeh, N.; Qualtrough, A.; Worthington, H.; Drucker, D. Antimicrobial activity of varying concentrations of sodium hypochlorite on the endodontic microorganisms actinomyces israelii, A. Naeslundii, Candida albicans and Enterococcus faecalis. Int. Endod. J. 2004, 37, 438-446. [CrossRef] [PubMed]

152. Foschi, F.; Cavrini, F.; Montebugnoli, L.; Stashenko, P.; Sambri, V.; Prati, C. Detection of bacteria in endodontic samples by polymerase chain reaction assays and association with defined clinical signs in italian patients. Oral Microbiol. Immunol. 2005, 20, 289-295. [CrossRef] [PubMed]

153. Puig-Silla, M.; Dasí, F. Oxidative stress parameters in saliva and its association with periodontal disease and types of bacteria. Dis. Markers 2015, 501, 653537. [CrossRef]

154. Ardila, C.M.; Alzate, J.; Guzmán, I.C. Relationship between gram negative enteric rods, aggregatibacter actinomycetemcomitans, and clinical parameters in periodontal disease. J. Indian Soc. Periodontol. 2012, 16, 65-69. [CrossRef] [PubMed]

155. Zambon, J.J.; Christersson, L.A.; Slots, J. Actinobacillus actinomycetemcomitans in human periodontal disease: Prevalence in patient groups and distribution of biotypes and serotypes within families. J. Periodontol. 1983, 54, 707-711. [CrossRef] [PubMed]

156. Son, J.S.; Kwon, T.-Y.; Kim, K.-H. Osteogenic evaluation of porous calcium phosphate granules with drug delivery system using nanoparticle carriers. J. Nanosci. Nanotechnol. 2015, 15, 130-133. [CrossRef] [PubMed]

157. Subbiah, R.; Hwang, M.P.; Van, S.Y.; Do, S.H.; Park, H.; Lee, K.; Kim, S.H.; Yun, K.; Park, K. Osteogenic/angiogenic dual growth factor delivery microcapsules for regeneration of vascularized bone tissue. Adv. Healthc. Mater. 2015, 4, 1982-1992. [CrossRef] [PubMed]

158. Uskoković, V.; Hoover, C.; Vukomanović, M.; Uskoković, D.P.; Desai, T.A. Osteogenic and antimicrobial nanoparticulate calcium phosphate and poly-(D,L-lactide-co-glycolide) powders for the treatment of osteomyelitis. Mater. Sci. Eng. C 2013, 33, 3362-3373. [CrossRef] [PubMed]

159. Jamshidi-Adegani, F.; Langroudi, L.; Ardeshirylajimi, A.; Dinarvand, P.; Dodel, M.; Doostmohammadi, A.; Rahimian, A.; Zohrabi, P.; Seyedjafari, E.; Soleimani, M. Coating of electrospun poly(lactic-co-glycolic acid) nanofibers with willemite bioceramic: Improvement of bone reconstruction in rat model. Cell Biol. Int. 2014, 38, 1271-1279. [CrossRef] [PubMed]

160. Ho, M.H.; Chiang, C.P.; Liu, Y.F.; Kuo, M.Y.P.; Lin, S.K.; Lai, J.Y.; Lee, B.S. Highly efficient release of lovastatin from poly(lactic-co-glycolic acid) nanoparticles enhances bone repair in rats. J. Orthop. Res. 2011, 29, 1504-1510. [CrossRef] [PubMed]

161. Lee, S.Y.; Koak, J.Y.; Heo, S.J.; Kim, S.K.; Lee, S.J.; Nam, S.Y. Osseointegration of anodized titanium implants coated with poly(lactide-co-glycolide)/basic fibroblast growth factor by electrospray. Int. J. Oral Maxillofac. Implant. 2009, 25, 315-320.

162. Irmak, G.; Demirtaş, T.T.; Çetin-Altındal, D.; Çalış, M.; Gümüşderelioğlu, M. Sustained release of $17 \beta$-estradiol stimulates osteogenic differentiation of adipose tissue-derived mesenchymal stem cells on chitosan-hydroxyapatite scaffolds. Cells Tissues Organs 2014, 199, 37-50. [CrossRef] [PubMed]

163. Manoukian, M.A.; Ott, S.V.; Rajadas, J.; Inayathullah, M. Polymeric nanoparticles to combat squamous cell carcinomas in patients with dystrophic epidermolysis bullosa. Recent Pat. Nanomed. 2014, 4, 15-24. [CrossRef] [PubMed]

164. Acharya, S.; Sahoo, S.K. PLGA nanoparticles containing various anticancer agents and tumour delivery by epr effect. Adv. Drug Deliv. Rev. 2011, 63, 170-183. [CrossRef] [PubMed]

165. Özel, T.; White, S.; Nguyen, E.; Moy, A.; Brenes, N.; Choi, B.; Betancourt, T. Enzymatically activated near infrared nanoprobes based on amphiphilic block copolymers for optical detection of cancer. Lasers Surg. Med. 2015, 47, 579-594. [CrossRef] [PubMed]

166. Dong, Y.; Feng, S.-S. Poly(D,L-lactide-co-glycolide) (PLGA) nanoparticles prepared by high pressure homogenization for paclitaxel chemotherapy. Int. J. Pharm. 2007, 342, 208-214. [CrossRef] [PubMed]

167. Dong, Y.; Feng, S.-S. Poly(D,L-lactide-co-glycolide)/montmorillonite nanoparticles for oral delivery of anticancer drugs. Biomaterials 2005, 26, 6068-6076. [CrossRef] [PubMed]

168. Su, W.-P.; Cheng, F.-Y.; Shieh, D.-B.; Yeh, C.-S.; Su, W.-C. PLGA nanoparticles codeliver paclitaxel and Stat3 sirna to overcome cellular resistance in lung cancer cells. Int. J. Nanomed. 2012, 7, 4269-4283. [CrossRef] [PubMed]

169. Li, Y.; Chen, F.; Nie, J.; Yang, D. Electrospun poly(lactic acid)/chitosan core-shell structure nanofibers from homogeneous solution. Carbohydr. Polym. 2012, 90, 1445-1451. [CrossRef] [PubMed] 
170. Ajalloueian, F.; Tavanai, H.; Hilborn, J.; Donzel-Gargand, O.; Leifer, K.; Wickham, A.; Arpanaei, A. Emulsion electrospinning as an approach to fabricate PLGA/chitosan nanofibers for biomedical applications. BioMed Res. Int. 2014, 2014. [CrossRef] [PubMed]

171. De Faria, A.F.; Perreault, F.; Shaulsky, E.; Hoover Arias Chavez, L.; Elimelech, M. Antimicrobial electrospun biopolymer nanofiber mats functionalized with graphene oxide? Silver nanocomposites. ACS Appl. Mater. Interfaces 2015, 7, 12751-12759. [CrossRef] [PubMed]

172. Gentile, P.; Chiono, V.; Carmagnola, I.; Hatton, P.V. An overview of poly(lactic-co-glycolic) acid (PLGA)-based biomaterials for bone tissue engineering. Int. J. Mol. Sci. 2014, 15, 3640-3659. [CrossRef] [PubMed]

173. Mehrasa, M.; Asadollahi, M.A.; Ghaedi, K.; Salehi, H.; Arpanaei, A. Electrospun aligned PLGA and PLGA/gelatin nanofibers embedded with silica nanoparticles for tissue engineering. Int. J. Biol. Macromol. 2015, 79, 687-695. [CrossRef] [PubMed]

174. Hild, N.; Schneider, O.D.; Mohn, D.; Luechinger, N.A.; Koehler, F.M.; Hofmann, S.; Vetsch, J.R.; Thimm, B.W.; Müller, R.; Stark, W.J. Two-layer membranes of calcium phosphate/collagen/PLGA nanofibres: In vitro biomineralisation and osteogenic differentiation of human mesenchymal stem cells. Nanoscale 2011, 3, 401-409. [CrossRef] [PubMed]

175. Yilgor, P.; Hasirci, N.; Hasirci, V. Sequential BMP-2/BMP-7 delivery from polyester nanocapsules. J. Biomed. Mater. Res. A 2010, 93, 528-536. [CrossRef] [PubMed]

176. Wang, C.-Z.; Fu, Y.-C.; Jian, S.-C.; Wang, Y.-H.; Liu, P.-L.; Ho, M.-L.; Wang, C.-K. Synthesis and characterization of cationic polymeric nanoparticles as simvastatin carriers for enhancing the osteogenesis of bone marrow mesenchymal stem cells. J. Colloid Interface Sci. 2014, 432, 190-199. [CrossRef] [PubMed]

177. Choi, G.H.; Lee, H.J.; Lee, S.C. Titanium-adhesive polymer nanoparticles as a surface-releasing system of dual osteogenic growth factors. Macromol. Biosci. 2014, 14, 496-507. [CrossRef] [PubMed]

178. Hassan, A.H.; Hosny, K.M.; Murshid, Z.A.; Alhadlaq, A.; Alyamani, A.; Naguib, G. Depot injectable biodegradable nanoparticles loaded with recombinant human bone morphogenetic protein-2: Preparation, characterization, and in vivo evaluation. Drug Des. Dev. Ther. 2015, 9, 3599-3606. [CrossRef] [PubMed]

179. Jung, Y.; Chung, Y.-I.; Kim, S.H.; Tae, G.; Kim, Y.H.; Rhie, J.W.; Kim, S.-H.; Kim, S.H. In situ chondrogenic differentiation of human adipose tissue-derived stem cells in a TGF- $\beta 1$ loaded fibrin-poly(lactide-caprolactone) nanoparticulate complex. Biomaterials 2009, 30, 4657-4664. [CrossRef] [PubMed]

180. Riffault, M.; Six, J.-L.; Netter, P.; Gillet, P.; Grossin, L. PLGA-based nanoparticles: A safe and suitable delivery platform for osteoarticular pathologies. Pharm. Res. 2015, 32, 3886-3898. [CrossRef]

181. Gajbhiye, V.; Palanirajan, V.K.; Tekade, R.K.; Jain, N.K. Dendrimers as therapeutic agents: A systematic review. J. Pharm. Pharmacol. 2009, 61, 989-1003. [CrossRef] [PubMed]

182. Bharali, D.J.; Khalil, M.; Gurbuz, M.; Simone, T.M.; Mousa, S.A. Nanoparticles and cancer therapy: A concise review with emphasis on dendrimers. Int. J. Nanomed. 2009, 4, 1-7.

183. Backlund, C.; Sergesketter, A.; Offenbacher, S.; Schoenfisch, M. Antibacterial efficacy of exogenous nitric oxide on periodontal pathogens. J. Dent. Res. 2014, 93, 1089-1094. [CrossRef] [PubMed]

184. Bengazi, F.; Lang, N.P.; Canciani, E.; Viganò, P.; Velez, J.U.; Botticelli, D. Osseointegration of implants with dendrimers surface characteristics installed conventionally or with piezosurgery ${ }^{\circledR}$. A comparative study in the dog. Clin. Oral Implant. Res. 2014, 25, 10-15. [CrossRef] [PubMed]

185. Galli, C.; Piemontese, M.; Meikle, S.T.; Santin, M.; Macaluso, G.M.; Passeri, G. Biomimetic coating with phosphoserine-tethered poly(epsilon-lysine) dendrons on titanium surfaces enhances wnt and osteoblastic differentiation. Clin. Oral Implant. Res. 2014, 25, e133-e139. [CrossRef]

186. Eichler, M.; Katzur, V.; Scheideler, L.; Haupt, M.; Geis-Gerstorfer, J.; Schmalz, G.; Ruhl, S.; Müller, R.; Rupp, F. The impact of dendrimer-grafted modifications to model silicon surfaces on protein adsorption and bacterial adhesion. Biomaterials 2011, 32, 9168-9179. [CrossRef] [PubMed]

187. Wang, T.; Yang, S.; Wang, L.; Feng, H. Use of poly(amidoamine) dendrimer for dentinal tubule occlusion: A preliminary study. PLOS ONE 2015, 10, e0124735. [CrossRef] [PubMed]

188. Zhang, H.; Yang, J.; Liang, K.; Li, J.; He, L.; Yang, X.; Peng, S.; Chen, X.; Ding, C.; Li, J. Effective dentin restorative material based on phosphate-terminated dendrimer as artificial protein. Colloids Surf. B Biointerfaces 2015, 128, 304-314. [CrossRef] [PubMed] 
189. Jia, R.; Lu, Y.; Yang, C.-w.; Luo, X.; Han, Y. Effect of generation 4.0 polyamidoamine dendrimer on the mineralization of demineralized dentinal tubules in vitro. Arch. Oral Biol. 2014, 59, 1085-1093. [CrossRef] [PubMed]

190. Ekambaram, P.; Sathali, A.A.H.; Priyanka, K. Solid lipid nanoparticles: A review. Sci. Rev. Chem. Commun. 2012, 2, 80-102.

191. Abed, N.; Couvreur, P. Nanocarriers for antibiotics: A promising solution to treat intracellular bacterial infections. Int. J. Antimicrob. Agents 2014, 43, 485-496. [CrossRef] [PubMed]

192. Drulis-Kawa, Z.; Dorotkiewicz-Jach, A. Liposomes as delivery systems for antibiotics. Int. J. Pharm. 2010, 387, 187-198. [CrossRef] [PubMed]

193. Jones, M.N. The surface properties of phospholipid liposome systems and their characterisation. Adv. Colloid Interface Sci. 1995, 54, 93-128. [CrossRef]

194. Salem, I.I.; Flasher, D.L.; Düzgüneş, N. Liposome-encapsulated antibiotics. Methods Enzymol. 2005, 391, 261-291. [PubMed]

195. Vyas, S.; Sihorkar, V.; Dubey, P. Preparation, characterization and in vitro antimicrobial activity of metronidazole bearing lectinized liposomes for intra-periodontal pocket delivery. Die Pharm. 2001, 56, 554-560.

196. Robinson, A.M.; Creeth, J.E.; Jones, M.N. The specificity and affinity of immunoliposome targeting to oral bacteria. Biochim. Biophys. Acta 1998, 1369, 278-286. [CrossRef]

197. Jones, M.N.; Francis, S.E.; Hutchinson, F.J.; Handley, P.S.; Lyle, I.G. Targeting and delivery of bactericide to adsorbed oral bacteria by use of proteoliposomes. Biochim. Biophys. Acta 1993, 1147, 251-261. [CrossRef]

198. Mugabe, C.; Halwani, M.; Azghani, A.O.; Lafrenie, R.M.; Omri, A. Mechanism of enhanced activity of liposome-entrapped aminoglycosides against resistant strains of pseudomonas aeruginosa. Antimicrob. Agents Chemother. 2006, 50, 2016-2022. [CrossRef] [PubMed]

199. Ko, A.; Yee, M.; Skupin-Mrugalska, P.; Düzgünes, N. Photodynamic therapy of porphyromonas gingivalis via liposome-encapsulated sensitizers. J. Calif. Dent. Assoc. 2013, 41, 827-830. [PubMed]

200. Kawazoe, A.; Inubushi, T.; Miyauchi, M.; Ishikado, A.; Tanaka, E.; Tanne, K.; Takata, T. Orally administered liposomal lactoferrin inhibits inflammation-related bone breakdown without interrupting orthodontic tooth movement. J. Periodontol. 2013, 84, 1454-1462. [CrossRef]

201. Wu, Z.; Ma, H.M.; Kukita, T.; Nakanishi, Y.; Nakanishi, H. Phosphatidylserine-containing liposomes inhibit the differentiation of osteoclasts and trabecular bone loss. J. Immunol. 2010, 184, 3191-3201. [CrossRef] [PubMed]

202. Sugano, M.; Negishi, Y.; Endo-Takahashi, Y.; Hamano, N.; Usui, M.; Suzuki, R.; Maruyama, K.; Aramaki, Y.; Yamamoto, M. Gene delivery to periodontal tissue using bubble liposomes and ultrasound. J. Periodontal Res. 2014, 49, 398-404. [CrossRef] [PubMed]

203. Liu, D.; Yang, P. Minocycline hydrochloride nanoliposomes inhibit the production of TNF- $\alpha$ in LPS-stimulated macrophages. Int. J. Nanomed. 2012, 7, 4769-4775. [CrossRef] [PubMed]

(C) 2016 by the authors; licensee MDPI, Basel, Switzerland. This article is an open access article distributed under the terms and conditions of the Creative Commons by Attribution (CC-BY) license (http://creativecommons.org/licenses/by/4.0/). 